\title{
LA CRISTOLOGÍA DEL PRÓLOGO DE SAN JUAN EN LA INVESTIGACIÓN JOÁNICA MÁS RECIENTE
}

\author{
Miguel Rodríguez Ruiz \\ Benediktbeuern (Alemania) \\ rodriguez@donbosco.de
}

\section{RESUMEN}

Este artículo analiza el Prólogo del Evangelio de Juan en relación con los estudios más recientes, como base para la interpretación de todo el Evangelio.

Palabras Clave: Evangelio de Juan, Prólogo, Cristología, Teología, Exegésis.

\section{ABSTRACT}

"The Christology of the Prologue to the Gospel of John according the newest joanic researching». This paper analyzes the Prologue to the Gospel of John and some others studies, as a basis of a comprehensive interpretation of the whole Gospel.

KeY WORDS: Gospel of John, Prologue, Christology, Theology, Exegesis.

\section{INTRODUCCIÓN}

1. 1. Jesucristo es el Verbo, Dios preexistente en el Principio, Creador y FUNDAMENTO DE TODA INTELIGIBILIDAD CREADA, EL VERBO ENCARNADO, EL UNIGÉNito del Padre, lleno de Gracia y verdad, Revelador del Padre (Jn 1,1-18)

En estos títulos entresacados del prólogo de San Juan (1,1-18) queda resumido el artículo de fe cristológico central de la revelación cristiana: "El Verbo que estaba junto al Padre desde toda la eternidad, y era Dios ${ }^{2}$, como el Padre, es la inteligibilidad misma por esencia, es creador y fundamento de toda inteligibilidad creada ${ }^{3}$. No solo creó el mundo $(1,3)$, sino que se hizo carne $(1,14 \mathrm{ab})$, y él, hecho hombre,

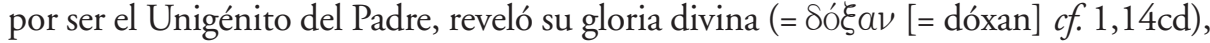
o sea, el Espíritu Santo. Aunque no se le nombre explícitamente en el prólogo, el Espíritu Santo no está ausente de él; aquí lo encontramos implícitamente por lo menos en la palabra "gloria" (= $\delta o ́ \xi \alpha \nu: 1,14 \mathrm{~cd})^{4}$.

El prólogo de San Juan no es solo uno de los textos más importantes del NT (= Nuevo Testamento), sino que no se encuentra un texto semejante en ninguna otra religión, sobre todo, por lo que se refiere a la afirmación neta y exclusivamente cristiana: "Y el Verbo se hizo carne" $(1,14 a)$ : "Como muy bien sabe la escuela joánica, es el pensamiento de la Encarnación la auténtica novedad cristiana — quizás incluso 
la única, pues todo lo demás, hasta incluso la teología trinitaria, se compone de elementos judío-helenísticos anteriores: 'El Logos se hizo carne' (Jn 1,14) — es el punto en que la mera especulación se quiebra y se liga o se enlaza estrechamente con la historia”; "... el cristianismo no es otra cosa que un judaísmo helenístico organizado de nuevo entorno a la afirmación de la Encarnación"; “... la cristología no es una helenización de elementos judíos; al contrario, consiste en pensar lo no griego" (el subrayado es de MR [= Miguel Rodríguez]; lo no griego es "la carne" en sentido bíblico, dirá Michel Henry; veremos más tarde que el filósofo francés $M$. Henry hace de este concepto el fundamento de su filosofía cristiana [nota de MR]); “... lo más peculiar y característico de la teología cristiana es la confesión: El Logos se ha hecho carne”. El prólogo es, además, el texto del NT que más repercusión e influencia ha tenido en el pensamiento y la cultura del mundo occidental, como afirman y demuestran los autores abajo mencionados, más profundos e influyentes en la historia del pensamiento, sobre todo, occidental, que se han ocupado del prólogo de San Juan: los Padres más importantes de la Iglesia (Orígenes, San Agustín), los teólogos medievales más relevantes (Juan Escoto Eriugena; Santo Tomás de Aquino; Maestro Eckhart), los filósofos del Idealismo alemán más influyentes (Fichte, Schelling y Hegel). En

${ }^{1}$ Según Jean Zumstein, «Der Prolog, Schwelle zum vierten Evangelium», en: Der Johannesprolog, (ed. G. Kruck), Darmstadt (WBG) 2009, 49-75, el prólogo del EvJn (= evangelio de San Juan) es, como dice el título traducido al español, el "umbral" o "dintel" (1,1-18), por el que entramos en el EvJn (1,19-20,31); en pág. 62, lo define así: "Prólogo es, en algunas obras literarias, el relato breve, cuya función consiste en orientar la lectura, controlar la descodificación o el desciframiento de la narración" que sigue a continuación "y prevenir falsas interpretaciones"; $c f$., también, íd., "Processus de relecture et reception de l'Écriture dans le quatrième évangile», EstBib 70 (2012): 37-54, esp. 39-42.

${ }^{2}$ En primer lugar, advierto al lector que empleo preferentemente en este artículo el título "el Verbo" en vez de "el Logos", para atenerme a la versión oficial española de la CEE, que ha decidido seguir usando esta versión tradicional en el mundo hispano. En segundo lugar, subrayo que en Jn 1,1c se predica del Verbo que es Dios, porque la palabra griega $\theta \in o ́ s$ (= theós [= Dios]) carece de artículo en este lugar: cf. Zerwick, Analysis Philologica Novi Testamenti Graeci, Roma 1960, 211; J. Beutler, Das Johannesevangelium, Friburgo Br. (Herder) 2013, 83; así también, Folker Siegert, «Der Logos, "älterer Sohn" des Schöpfers und "zweiter Gott". Philons Logos und der "Johannesprolog"”, en: Kontexte des Johannesevangeliums (J. Frey - U. Schnelle [eds.]), Tubinga (Mohr Siebeck) 2004, págs. 285-286: Que el Verbo es Dios, significa que participa de la misma naturaleza divina de Dios Padre.

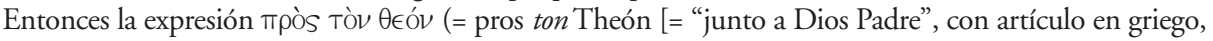
pero que no se traduce el artículo al español]) no puede significar ni referirse a la misma persona del Verbo, sino necesariamente solo a la del Padre ( $c f .1,1 \mathrm{~b} .2$ y $14 \mathrm{~d})$. El evangelista distingue, por tanto, en 1,1-2 entre la persona del Padre y la del Verbo: dos personas divinas distintas que poseen la misma naturaleza; dos personas distintas en una sola naturaleza común, como afirma el concilio calcedonense.

${ }^{3}$ Acerca de la inteligibilidad del Logos o Verbo y de las relación entre Logos y Sabiduría $c f$. F. Siegert, ibíd. (cf. nota 1), págs. 277-280.

${ }^{4}$ Cf. San Gregorio de Nisa, Homilia 15, donde afirma que "ninguna persona por poca inte-

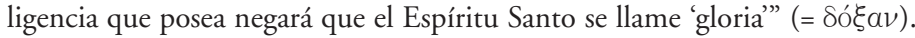

${ }^{5}$ Cf. F. Siegert, ibid. (cf. nota 1), págs. 277-293, aquí esp. 288.290. 
las págs. 7-255, que hacen más de la mitad de libro, se estudian extensamente en sendos capítulos los autores que acabamos de mencionar ${ }^{6}$. También habría que citar el Fausto de Goethe, que afirma del Logos joánico: "Es lo que mantiene unido al mundo en lo más íntimo de su ser" . Además del libro que acabamos de mencionar, se ha publicado en la última década Der Johannesprolog, que consta de una serie de artículos en los que diversos autores alemanes estudian el prólogo de San Juan desde varios puntos de vista y desde su importancia en la historia de la teología y filosofía $(1,1-18)^{8}$. Una cuestión importante que ya estudió Harnack es la que se refiere a la función que desempeña el prólogo de San Juan con relación a todo el EvJn, y nosotros podríamos añadir a las cartas joánicas, sobre todo, 1-2 Jn. Los autores de los últimos años han dado una explicación convincente de la íntima relación del prólogo con el corpus del EvJn, sobre todo, con relación a la cristología joánica. En primer lugar, quisiera citar el libro de Hans Weder sobre el prólogo de San Juan?. Me parece, por tanto, muy acertada la opinión de M. Theobald, según la cual el prólogo del EvJn se añadió al final, cuando el evangelista había terminado su EvJn: págs. 7-255.

${ }^{6}$ Cf. M. Enders / R. Kühn, "Im Anfang war der Logos ...", Friburgo Br. (Herder) 2011,

7 La cita en alemán dice así “... was die Welt im innersten zusammenhält”, y está tomada del artículo de Jörg Frey, "Between Tora and Stoa. How could Readers Have Understood the Johannine Logos?”, en: Jan van der Watt, Culpepper und Udo Schnelle (eds.), The Prologue of the Gospel of John. Literary, Theological and Philosophical Contexts. Papers Read at the Colloquium Joanneum 2013 (WUNT 2), Tubinga: Mohr - Siebeck, 186-231, aquí 200.

${ }^{8} C f$. Günter Kruck (ed.), Johannesprolog, (cf. nota 1), que tuvo su origen en un seminario en Francfort junto al Meno en 2007, donde se contienen los siguientes artículos sobre el prólogo de san Juan: J. Zumstein, "Der Prolog, Schwelle zum vierten Evangelium” (49-75); J. Beutler, “Der Johannes-Prolog - Ouvertüre des Johannesevangeliums" (77-106); A. Wucherpfennig, "Gnostische Lektüre des Johannesprolos am Beispiel Herakleons" (107-130); L. Hell, "Wort vom Wort. Augustinus, Thomas von Aquin und Calvin als Leser des Johannesprologs" (131-153). En el libro dedicado a la Wirkungsgeschichte del prólogo de San Juan de los autores M. Enders / R. Kühn, "Im Anfang war der Logos ...", hay dos interesantes artículos de R. Kühn dedicados a la fenomenología del filósofo y fenomenólogo francés Michel Henry: "Der Johannesprolog in der Phänomenologie", (259-305), especialmente: "Lebensphänomenologie und transzendentale Geburt" (287-305). Este último artículo es casi idéntico al que R. Kühn publicara con ligeras variantes, más bien formales, dos años antes en: Gregorianum 90 (2009) 274-296. Una de sus últimas obras es Incarnation. Une philosophie de la chaire, Éditions du Seuil, octubre 200. Está traducida al español: Michel Henry, Encarnación, Salamanca (Sígueme) 2001, 345 págs.

${ }^{9}$ Hans Weder, Ursprung im Unvordenklichen (= "Origen en lo impensable"), Eine theologische Auslegung des Johannesprologs, Neukirchen (Neukirchener [BThSt 70]) 2008, 125: La vinculación del himno (Jn 1,1-18) con el EvJn (1,19ss.) tiene lugar en 1,18c, que pudo ser sugerida por "la comparación entre la Ley y la Gracia y la orientación sapiencial del himno $(1,17 ; c f .1,14.16)$, que subyace al prólogo; por otra, por las inserciones relativas a Juan el Bautista ( $c f .1,6-8.15 .19$ ss.), que según la tradición cristiana están al principio del ministerio de Jesús; $c f$. , además, J. Beutler, "Der Johannes-Prolog - Ouvertüre des Johannesevangeliums", en: Der Johannesprolog (G. Kruck ed.) (cf. nota 1), 77-106, esp. 99-101); J. Beutler, Das Johannesevangelium, Friburgo Br. (Herder) 2013, 81-82. 
“... el prólogo — (no el Himno que subyace al prólogo: aclaración de MR)— no pertenece al principio de la historia de la tradición joánica, sino a su final”; “... el comienzo actual del evangelio se debe a la redacción", "pues no es la noción del Logos la que constituye la estructura del EvJn sino la de Hijo del hombre, que ha bajado del cielo y sube allá para ser glorificado, y es el Hijo por excelencia"; "... el autor del prólogo acentúa la unidad del Logos y su relación con Dios Padre $(1,1-2)$ y con las creaturas $(1,3 ; 1,14 \mathrm{ab})$; la unidad personal con ambas partes es indisoluble, pues de lo contrario el Verbo $(1,1-5.14)$ o Jesucristo $(1,17 b)$ no podría ser el Salvador de los hombres". Visto retrospectivamente, el prólogo de San Juan es el fundamento

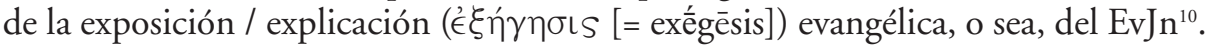

En los últimos años han continuado apareciendo en el mundo exegético alemán comentarios sobre el EvJn - siempre inagotable e incombustible desde el punto de vista exegético-teológico- en los que se ha prestado especial atención al prólogo $(1,1-18)$. El interés y el afán por indagar quién es "Jesús de Nazaret" (Jn 1,45), según el EvJn, no cesan. No solo en el prólogo sino también en el primer capítulo del EvJn 1,19-51 encontramos una colección de títulos cristológicos sublimes, de soberanía divina, aplicados con gran profusión a Jesús que nos revelan la importancia excelsa de Jesús de Nazaret. M. Theobald ve, por tanto, en el resto del primer capítulo del EvJn (v. 19-51) intentos del redactor por hacer una introducción más amplia al EvJn, que llegaría a Jn 2,11 $1^{11}$.

Aunque por razones de espacio nos ocupemos principalmente del prólogo de San Juan, será necesario de vez en cuando echar algún vistazo a todo el EvJn. Sumamente importante para comprender la finalidad del EvJn son los últimos versículos con que el evangelista concluye y cierra el EvJn. El evangelista finaliza su EvJn proclamando a Jesús (de Nazaret) en la confesión final de fe "como el Cristo, el Hijo de Dios": "... para que creáis que Jesús es el Cristo, el Hijo de Dios, y para que, creyendo, tengáis vida en su nombre" (20,31). Al final del EvJn constituyen

${ }^{10} \mathrm{M}$. Theobald, Die Fleischwerdung des Logos. Studien zum Verhältnis des Johannesprologs zum Corpus des Evangeliums und zu 1 Joh, Münster (Aschendorff) 1988, 489. 491-492. En mi amplio artículo "Apostolicidad y ministerio en el evangelio según Juan y las cartas de Juan": Sal. 71 (2009) 239-292, esp. 242-244, comprobé las diversas opiniones de los estudiosos del corpus joánico (EvJn, 1-3 Jn) entorno a su composición literaria. Si es verdad que en la época de la antigua Quellenkritik, p. ej., R. Bultmann admitía muchos autores y redactores para el EvJn y la 1Jn, en las últimas décadas se han reducido mucho los supuestos autores y redactores del EvJn: $c f$., por una parte, las opiniones de E. Ruchstuhl - P. Dschulnigg; P. Pokorny - U. Heckel; por otra, autores de renombre como H.-J. Klauck y J. Frey afirman que "desde el punto de vista lingüístico-estilístico el parentesco entre la $1 \mathrm{Jn}$ y el EvJn es "mayor que entre el evangelio de Lucas y los Hch. Por su parte, M. Hengel, Johanneische Frage, Tubinga (Mohr-Siebeck: WUNT 67) 1993, 123 destaca la homogeneidad y semejanza de estilo y lenguaje en el corpus joánico.

${ }^{11}$ M. Theobald, ibid., 438-461. 
estos dos títulos un resumen de la alta cristología del EvJn en los que quedan incluidos los demás anteriormente mencionados (Verbo, Hijo del hombre), ya que en la conclusión final se supone se contengan las ideas más importantes del EvJn enunciadas anteriormente ${ }^{12}$. Por lo que respecta al título "el Cristo", no debería traducirse en este lugar "el Mesías" (así la Sagrada Biblia de la CEE), como al principio del EvJn, donde se menciona a Andrés, recién convertido en discípulo de Jesús, que, a su vez, gana a su hermano Simón como discípulo de Jesús $(1,41)$. El contexto del texto que acabamos de mencionar era judío, y el título "Cristo" o "Mesías" estaba puesto en boca de judíos cuya mesianología era la tradicional judía, acomodándose incluso el Bautista al modo de hablar de sus interlocutores judíos; y así Jesús o el evangelista hacen hablar a la samaritana como si fuera judía (4,25.29), que esperaría como los judíos un Hijo de David (cf.7,41-42) o como dice el salmo apócrifo de Salomón (= PsSal 17,21-46) un rey mesiánico, ungido por Dios, liberador del pueblo de Israel (cf. Jn 1,20.25; 3,28; 7,26.27.31.41-42; 10,24; 12,34). Hay, sin embargo, cuatro menciones del título "el Cristo", que son confesiones netamente cristianas, como la puesta en boca de Marta $(11,27)$ o la confesión cristiana ya mencionada del final del EvJn $(20,31)$ o la proclamación que se encuentra al final del prólogo: "... la gracia y la verdad se han hecho realidad por medio de Jesucristo" $(1,17 \mathrm{~b})$ y la autoproclamación de Jesús en la oración sacerdotal: “... que conozcan ... a tu enviado, Jesucristo". En estas cuatro confesiones adquiere el título "el Cristo" $(11,27 ; 20,31)$ o "Jesucristo" (1,17b; 17,3b), sea por su unión con el título "el Hijo de Dios" $(11,27 ; 20,31)$ o con "Jesús por quien se han hecho realidad "la gracia y la verdad" o por ser "el enviado del Padre" (1,17b; 17,3b), connotaciones que elevan el título "el Cristo" a su máximo significado cristológico: las expectativas mesiánicas del pueblo de Israel quedan ya desde el principio del EvJn (1,1-5.8-18) superadas completamente. Los dos títulos "El Cristo" y "El Hijo de Dios" constituyen, pues, una unidad cristológica, ya que - para el lector o lectora verdaderamente creyenteambos están unidos en la persona divina del Verbo encarnado — pues el Verbo carece de persona humana según fe católica y la sana teología; sea esto dicho contra los frecuentes errores cristológicos que se repiten hoy en día inconscientemente-; los títulos "Cristo" e "Hijo de Dios" son inseparablesde la persona divina del Verbo encarnado.

${ }^{12}$ El capítulo 21,1-25 fue publicado muy probablemente junto con los capítulos 1-20 por los discípulos del evangelista Juan, del cual dan testimonio; por lo menos, los últimos versículos de Jn 21,24-25 no pudieron ser redactados por el mismo evangelista pues ya había muerto y había terminado su obra con los versículos 20,30-31. Que el material del capítulo 21,1-23 proceda del mismo evangelista, si bien con retoques de los discípulos que lo añadieron a la obra del evangelista, es muy probable. Para más información y argumentos, $c f$. Miguel Rodríguez Ruiz, Der Missionsgedanke des Johannesevangeliums. Ein Beitrag zur johanneischen Soteriologie und Ekklesiologie, Würzburgo (Echter: FzB 55) 1987, 278-279. 
Esto, sin embargo, no libra al discípulo o la discípula de Cristo de tener que afrontar valientemente ya en el mismo prólogo el desafío cristológico de que Jesús en cuanto "el Verbo "es Dios" (1,1c). Tal tentación la superan gracias a que su fe está inspirada o iluminada y elevada o ayudada por la gracia divina, que los ayuda a descubrir y confesar que Jesús de Nazaret no es solo el Mesías o Cristo esperado por los judíos (1,41-42.45.49-51), sino, más aún, "el Cristo" o "Jesucristo", "el Hijo de Dios" (Jn 20,31), el Verbo encarnado (1-2.14), que recibe títulos divinos inconcebibles para el no

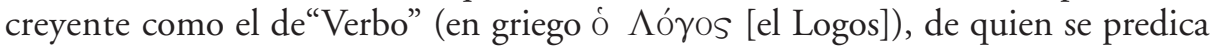
nada menos que el título "Dios": "Y Dios era el Verbo" $(1,1 ; c f .20,28)$. Se le añaden a Jesús al final del prólogo o el himno los títulos el "Unigénito del Padre" $(1,14)$, el "Dios unigénito" (1,18 [= lectura más probable; menos probable es "Hijo unigénito"]). En el resto del capítulo primero aparecen una serie de títulos soberanos, supremos e insuperables como, "Cordero de Dios que quita el pecado del mundo" $(1,29.36)$, "El Hijo del hombre" $(1,51)$, que sustituirá a lo largo del EvJn al título "Verbo encarnado", que aparece solo dos veces en el prólogo del EvJn $(1,1.14)$. Cf., sin embargo, las dos cartas joánicas ( $1 \mathrm{Jn}$ 4,2; 2 Jn 7), donde se formula con otras palabras la misma verdad de la Encarnación en perfecta concordancia con Jn 1,1-2.14. Conviene invocar de nuevo en este lugar la opinión de $\mathrm{M}$. Theobald acerca de la labor del redactor o redactores ( $c f .21,24 \mathrm{c}$ "sabemos" [= ol $\delta \alpha \mu \in \nu$ : óidamen]) del prólogo $(1,1-18)$ y del resto del capítulo primero $(1,19-51)$ en colaboración con el Presbítero antidoceta de las cartas joánicas (2 Jn 1[7; cf. 1 Jn 4,2]; 3 Jn 1) ${ }^{13}$. Estas observaciones tienen importancia para subrayar el significado genuinamente católico y ortodoxo de la Cristología del prólogo y del EvJn en general. Estos títulos del prólogo de San Juan expresan y subrayan la realidad verdadera de Jesús de Nazaret: "Verdadero Dios y verdadero hombre", conforme al concilio de Calcedonia.

\subsection{La FenOMENOLOGía de Michel Henry y su aplicación al prólogo de SAN Juan Y AL EVJN EN GENERAL}

El fenomenólogo francés M. Henry (1922-2002) se ha ocupado en su vida filosófica de la interpretación fenomenológica del EvJn y su prólogo ${ }^{14}$. La finalidad

${ }^{13}$ M. Theobald, ibid. (cf. nota 10), 489.491-492.

${ }^{14}$ Rolf Kühn, asiduo y comprometido seguidor suyo es traductor de su obra francesa Incarnation al alemán, y propagador de su fenomenología trascendental radical y de su aplicación al EvJn en el mundo alemán. La versión española de Michel Henry, Encarnación. Una filosofía de la carne, Salamanca (Sígueme) 2001, 345 págs., es traducción de su obra fancesa Incarnation. Une philosophie de la chaire, Paris (Éditions du Seuil), 2000, págs., y ha estado dirigida por el filósofo español Miguel García-Baró, quien se ha preocupado de dar a conocer en España el pensamiento del filósofo francés, como Rolf Kühn lo hace en Alemania. 
de la fenomenología consiste en observar cómo aparece y se muestra el fenómeno, el acontecimiento; el fenomenólogo no especula sobre lo que está debajo del fenómeno, sino que se fija en la manera peculiar de manifestarse el evento o fenómeno. Este descubrimiento no es nuevo para los exegetas educados en el método histórico crítico, que examinan el texto sagrado con ojo avizor o escudriñador. Lo que distingue la fenomenología de M. Henry de la de sus antecesores es que no se para ni queda paralizado en el mostrarse o aparecer de los fenómenos mundanos; por eso habla de fenomenología "trascendental radical". Esta significa para Michel Henry, por una parte, la superación de todo lo humano, intramundano o visible en el acontecimiento o "evento", que queda de la parte de acá del mundo, en el aspecto meramente visible o mundano del fenómeno o evento mundano, lo cual comporta condenarse al fracaso total. M. Henry para quien Jesús de Nazaret en cuanto Cristo es la Verdad de la vida por excelencia, que se opone radicalmente a la "verdad del mundo" — que aquí escribo con minúscula—, a sus leyes y a su lógica. Para ascender a la Verdad de Cristo hay que partir de la vida personal e íntima, y dejando atrás lo mundano o visible y la falsa ciencia, lanzándose con toda la fuerza para alcanzar a Cristo, como diría San Pablo (Flp 3,13b-14). Este texto paulino podría expresar adecuadamente la fenomenología de M. Henry. Ciertamente para M. Henry el punto de partida es concretamente la "carne" personal de Cristo, pero también la mía y la del prójimo (Mt 25,34-46; 1 Jn 3,16-18). Porque somos de "carne", sufrimos, sentimos, como sufrió Cristo, y somos personas con un mundo interior afectivo, como lo son también nuestros prójimos. Ese sentir y sufrir es para M. Henry su "cogito" en alusión al "cogito" de Descartes, y, por lo menos tan seguro, y tal vez más. M. Henry critica en Descartes su dependencia de Galileo Galilei, quien introdujo, según M. Henry, el reduccionismo en la filosofía y la ciencia moderna. En cambio, afirma M. Henry, no se puede desechar el sentimiento, sufrimiento, la carne. Al sentir y sufrir experimentamos que existimos, o tal vez mejor aún, que vivimos. Si la vida puramente personal e interior carecía de importancia para la filosofía griega, y, mucho más, a partir de Galileo Galilei y Descartes, para la filosofía moderna, incluído M. Heidegger, no fue así en el Cristianismo, donde la vida es fundamental, pues de lo contrario no habría más que la muerte. El pensador Maine de Biran (1766-1824), al principio partidario del cogito de Descartes, supo reaccionar y liberarse de su reduccionismo, planteándose la pregunta decisiva: “¿Existe una apercepción inmediata interna?”. M. Henry partió de las intuiciones de este compatriota suyo para fundamentar su teoría $^{15}$. La fenomenología radical cristiana de M. Henry encuentra su lugar ideal de aplicación en el prólogo de San Juan, porque aquí M. Henry encuentra el artículo clave de su fenomenología, que es la Encarnación (Jn 1,14), el título cristológico

${ }^{15}$ Michel Henry, Filosofía y fenomenología del Cuerpo, Salamanca (Sigueme) 2007, 21. 
"el Verbo" y su "archi-inteligilidad" $(1,1-2)$, fundamento de toda inteligibilidad en general $(1,3)$, y el concepto "vida" $(1,4)$, que es fundamental en la fenomenología. Desde la fenomenología se plantea $\mathrm{M}$. Henry el concepto radical de vida que tiene su realización en Jesús de Nazaret en cuanto Cristo. M. Henry ha criticado severamente a los fenomenólogos anteriores (de Edmund Husserl a Merleau-Ponty, pasando por Martin Heidegger), porque no han logrado trascender radicalmente lo mundano ni llegar a la fuente pura, eterna y divina, lo que es solo posible por la fe en Cristo. M. Henry ha tratado de ir más allá de la mundanidad visible, sin quedarse atrapado y aprisionado en los fenómenos mundanos. Aquí es el tiempo de criticar a M. Henry. El que quiera llegar a la verdad tendrá que disponer, además, de otras fuentes o lugares y criterios, para llegar al mensaje del texto que examina, pues con solo un fenómeno o una aparición podría equivocarse. Esto es evidente para un católico que se guía por la fe de la Iglesia. El error de M. Henry fue que rechazó para su cristología la definición del concilio de Calcedonia: la unión de la naturaleza divina del Verbo con la naturaleza humana asumida por él mismo en su persona. En consecuencia, se queda M. Henry en el monofisitismo, lo cual le resulta más agradable para sus tendencias místicas o pseudomísticas, sin preocuparse del magisterio de la Iglesia, al ejemplo del Maestro Eckhart. Y esto significa que M. Henry no toma seriamente la "carne" de Cristo y del prójimo. Es lo que reprocha San Juan a algunos cristianos en su primera carta: "Pero si uno tiene bienes del mundo y, viendo a su hermano en necesidad, le cierra sus entrañas, ¿cómo va a estar en el amor de Dios?" (1 Jn 3,17).

Otro error de M. Henry, —y su discípulo alemán R. Kühn— consiste en que rechazan el concepto de "ser" de la metafísica clásica y aceptan solo, en cambio, el concepto de "vida", del que se ocupa principalmente la fenomenología. Cierta-

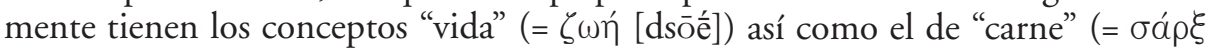
[sarx]) en el NT (Nuevo Testamento) una importancia soteriológica y salvífica importantísima, de la que carecen los contextos filosóficos profanos. La carga explosiva, dicho sea en sentido figurado, o las implicaciones salvíficas del término joánico

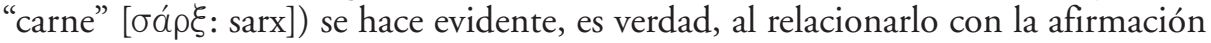
de Juan Bautista señalando a Jesús: "Este es el Cordero de Dios, que quita el pecado del mundo" (Jn 1,29 [cf., además, Is 52,13-53,12]; Jn 19,34-36; cf., también, Jn 6,51-56). Sin embargo, es desacertado excluir absolutamente el concepto metafísico de "ser", porque si es verdad que en algunos casos el concepto de "ser" tiene un significado exiguo, pobre y escaso, no es así cuando se aplica a Dios ${ }^{16}$.

El adjetivo "radical" no tiene nada que ver con violencia, sino más bien con "raíz", "origen primordial”, fontanal puro, y significa para M. Henry y su discípulo

${ }^{16}$ Cf. Aristóteles, Metafisica, edición trilingüe por Valentín García Yebra), Madrid (Gredos) 1982, libro IV; 150-215. 
Rolf Kühn el origen más puro y cercano a la fuente misma de la Vida divina y Verdad en donde no hay distancia alguna entre la Fuente divina y su Primer-Viviente, o sea, el Logos o el Verbo, como le llama Henry "Primer-Viviente, fundamento de la inteligibilidad misma creada, lo que supone la absoluta separación y apartamiento del mundo y todo lo mundano. Esto se da en Cristo en cuanto es el Unigénito del Padre, y en los creyentes en cuanto que son engendrados por la Gracia divina y la Fe en Cristo.

Hay, sin embargo, algunos otros puntos con los que tampoco estoy de acuerdo con Henry y Kühn: que hablen de las relaciones interpersonales de las tres personas divinas, como si tratasen de describirlas por dentro con toda precisión, lo cual suena a semirracionalismo; en segundo lugar, que no mencionen la regeneración del cristiano por medio del Bautismo ( $c f$. Rom 6,1-14), sino solo por la fe, que no parece ser la auténtica fe cristiana, sino la protestante de Kierkegaard o Maestro Eckhart, hablando solo de ser generados o engendrados los creyentes por la fe - ¿de qué fe se trata? - como "hijos de Dios" y sin hablar del Espíritu Santo (Cf., sin embargo, Jn 3,3-10).

\subsection{LA DIVINIDAD DEL VERBO, SU PREEXISTENCIA Y EL ACOPLAMIENTO DE LA ESTRUC- TURA DE LOS SIETE TEXTOS DE “PREEXISTENCIA DE JESÚS" A LA ESTRUCTURA GENERAL del Evangelio de San Juan Según F. Kunath}

Friederike Kunath, exegeta luterana, ha estudiado en una excelente tesis doctoral las afirmaciones sobre la preexistencia de Jesús en el EvJn, aunque no esté exenta de algún que otro error ${ }^{17}$. Para ello ha escogido seis lugares del EvJn en los que se encuentra cada vez una afirmación sobre la preexistencia de Jesús dentro de un contexto relacional de preexistencia, y en los que se dan los rasgos estructurales del motivo de la preexistencia. Kunath al hablar de textos "relacionales" de preexistencia se refiere a los seis pasajes de $1,15.30 ; 6,62 ; 8,58 ; 17,5 \mathrm{~d}$.24i, excluyendo como no relacional el pasaje de Jn 1,1-2, porque la afirmación de preexistencia al principio del prólogo carece, a su parecer, del contexto relacional de los otros seis pasajes que califica de relacionales. Los seis textos relacionales de preexistencia de Jesús forman un grupo que consta de elementos particulares estructurados análogamente y relacionados entre sî"18. La falta de concreción personal del Logos en 1,1-2, rayando en el mito, opinión a la que se inclina su mentor J. Frey, con la que simpatiza F. Kunath, es la razón por la que esta considera el pasaje de Jn 1,1-2 como texto o afirmación

${ }^{17}$ Cf. Friederike Kunath, Die Präexistenz Jesu im Johannes-Evangelium, Berlin / Boston

(Walter de Gruyter) 2016, 421 págs., espec. 47-363.

${ }^{18}$ Cf. ibid., 313. 
no relacional de preexistencia. A mi parecer, en cambio, los oyentes o lectores / lectoras de la comunidad joánica sabían muy bien que el Verbo o el Logos era una persona divina verdadera en el principio junto al Padre, creador de poder infinito, pleno de vida infinita y por antonomasia luz iluminadora de los hombres $(1,1-5)$. Y ese grupo de creyentes ortodoxos era la parte más importante de la iglesia joánica — que no cayó en la herejía doceta, de que hablan las cartas joánicas 1-2 Jn-, cuya cristología del Verbo o Logos estaba más influida por la doctrina de la sabiduría del AT (= Antiguo Testamento) que por otras doctrinas filosófico-religiosas paganas del entorno. F. Kunath se pregunta "en qué forma y en qué contextos habría hablado la comunidad joánica de la preexistencia de Jesús". Su respuesta es que "el estilo narrativorecordativo del evangelio no se puede identificar sin más con la vida litúrgica y devocional de aquellos que vivían con este texto", como parece opinar Hurtado ${ }^{19}$. Sin embargo, tengo por cierto que en la comunidad joánica se dió culto o se veneró públicamente a Jesucristo, el Verbo encarnado: los restos del himno que subyace al prólogo de San Juan (1-5.9-12ab.14.16) lo indican; igualmente exclamaciones como "Este es el Cordero de Dios, que quita el pecado del mundo" (1,29.34.36.49; 6,48-58.68; 7,37-39; 9,35-38; 11,25-27; 13,13; 14,6-11.20-24; 15,1-17; 17,3; 19,14.34-37; 20,28); en estos lugares del EvJn podrían resonar ecos del culto divino y plegaria de la iglesia joánica ${ }^{20}$. Desconocemos cuáles fueron los orígenes de la herejía que negaba la encarnación de Jesucristo ( 1 Jn 4,2; 2 Jn 7), herejía que fue rechazada por la mayoría de la comunidad ${ }^{21}$.

La definición de F. Kunath de los pasajes de"preexistencia de Jesús" en el EvJn es la siguiente: El objeto de estudio conceptuado como "preexistencia de Jesús" consta de siete frases del evangelio de Juan que presentan una estructura semántico-sintáctica

\section{${ }^{19}$ Cf. ibid., 370. Cf. próxima nota 20.}

${ }^{20}$ Cf. R. Schnackeburg, Das Johannesevangelium, I, Friburgo Br. (Herder) 1965, 321-328, aquí 327: "El cuarto evangelista puede haber tomado sugerencias del lenguaje cultual (de la iglesia joánica) que a su estilo ha sabido hacerlas fecundas para su cristología". F. Kunath, ibid., 370, se muestra crítica con Larry W. Hurtado, Lord Jesus Christ, (Grand Rapids, Mich. [Eerdmans] 2010, 81-109, y previene contra "rápidas conclusiones como que en el culto divino y plegaria de la comunidad joánica se hayan usado afirmaciones de preexistencia” de Jesús, si bien se podría sospechar en Jn 17, donde se advierte cierta relación con la oración de la comunidad, ya que Jesús habla extrañamente de sí en tercera persona como Hijo de Dios e incluso se denomina a si mismo "Jesucristo", pero en general no niega la exegeta luterana absolutamente que en el EvJn se encuentren ecos y resonancias de himnos y confesiones que se empleaban en el culto divino y la plegaria de la iglesia joánica. F. Kunath parece acercarse a la opinión de R. Schnackenburg.

${ }^{21} C f$. F. Kunath, ibid., 332-341. No estoy muy seguro por qué el pasaje de preexistencia en Jn 1,1-2 carece, según Kunath, de la característica relacional de preexistente. ¿Es tal vez porque el Logos en esos versículos tiene una existencia muy pobre y exigua, rayando en el mito, mientras que en los otros seis pasajes los personajes son reales: Jesucristo, Juan Bautista $(1,15.30)$, discípulos incrédulos que abandonan a Jesús $(6,62)$, los judíos que intentan apedrearle $(8,58-59)$, en la Oración sacerdotal Jesús se dirige al Padre? (17,5d.24i). 
común (y homogénea). Empleando un lexema temporal (con prefijo) "pre"22 se construye una afirmación sobre la existencia de Jesús o se puede significar también su existencia por medio de un contenido verbal. Estas frases pueden por tanto simplificarse con una frase como "Jesús existió antes (de)"2z. La tesis doctoral de F. Kunath consta de seis capítulos que mencionamos a continuación, que están precedidos al principio de uno en que se resume la historia de la investigación acerca de la preexistencia de Jesús en el EvJn (1-45). Este primer capítulo se refiere a "los comienzos de la Cristología", primero en el NT, que con San Pablo y, sobre todo, San Juan alcanza su punto culminante; luego brevemente se refiere Kunath a la Cristología del apologeta Justino y, en tercer lugar a las definiciones dogmáticas de los primeros concilios: Nicea (325: “... Jesucristo, ... verdadero Dios de Dios verdadero, engendrado, no creado, de la misma sustancia o naturaleza del Padre [en griego: homousion]); el Niceno-Constantinopolitano subraya la preexistencia (381: “... engendrado del Padre antes de todos los siglos”); el Concilio de Calcedonia destaca la unión de la naturaleza divina y humana en la persona del Verbo encarnado, pues una persona humana no existe en Cristo, el Verbo encarnado (451: Nuestro Señor Jesucristo ..."según su divinidad fue engendrado del Padre antes de todos los siglos, en los últimos días según la humanidad engendrado por nosotros y por nuestra salvación de la Virgen María, la Madre de Dios"). El que un autor o autora protestante incluya las definiciones de los concilios de los cinco primeros siglos es de alabar; no contradice la doctrina protestante, porque no hace otra cosa que seguir a Lutero, que admitió la tradición quinquesaecularis (= de los cinco primeros siglos) de la Iglesia. Por lo que se refiere a los exegetas modernos hay un grupo notable que aceptan la divinidad y preexistencia del Verbo encarnado, y no las entienden míticamente sino realmente, si se exceptúa a R. Bultmann, que considera al Logos y su preexistencia como mitos; en cambio, R. Schnackenburg, católico, le contradice decididamente; otros autores que admiten la divinidad de Jesucristo y su preexistencia son Hamilton-Kelly; J. Frey; William Loader; Udo Schnelle, W. Thüsing. Estos están de acuerdo en admitir la doctrina de la divinidad y de la preexistencia del Verbo encarnado, aunque en algunos puntos introduzcan aspectos particulares, tratando de perfilar sus respectivas opiniones ${ }^{24}$.

En el últino capítulo, al final de la tesis, que lleva por título "El Logos y el "principio" (313-363), la autora trata retrospectivamente de conciliar la estructura que forman las afirmaciones de los lugares de "preexistencia de Jesús" con la estructura

\footnotetext{
${ }^{22}$ Prefijo derivado del latino prae, que significa "antes" y expresa anterioridad en el tiempo o en el espacio: $c f$. M. Moliner.

${ }^{23}$ Cf., ibid., 41-42. Hay que advertir que la expresión "siete" frases no está en contradición con los "seis" lugares o pasajes en que se menciona la preexistencia. Se dice "siete frases" porque se ha añadido ahora la peculiar afirmación del principio del prólogo (Jn 1,1-2), que desempeña un papel muy importante dentro de las frases de preexistencia, aunque F. Kunath no la considere relacional.

${ }^{24} C f$. F. Kunath, ibid., 1-40.
} 
general del EvJn. En este último capítulo relaciona los versículos de Jn 1,1-2 con los seis pasajes relacionales en que se menciona la "preexistencia de Jesús", pero comenzando regresivamente desde atrás a partir de las dos últimas menciones de Jn 17,5d.24i. hasta llegar al principio del prólogo de San Juan (1,1-2). Los capítulos que estudian los pasajes sobre la "preexistencia de Jesús" en el centro de la tesis doctoral son los siguientes: "El testimonio de Juan sobre la preexistencia del Logos encarnado" (1,15 [47-107]); "El testimonio de Juan sobre la preexistencia de Jesús" (1,30 [109-177]); "La alusión de Jesús a su retorno al lugar de su preexistencia" (6,62 [179-239]); "La afirmación de Jesús de que él es anterior a Abrahán" (8,58 [241-277]); "Las alusiones de Jesús a su existencia antes de que el mundo existiera" (17,5d.24i [279-311]).

Las seis afirmaciones de Juan el Bautista sobre la preexistencia de Jesús $(1,15.30)$ y de Jesús mismo sobre su propia preexistencia $(6,62 ; 8,58 ; 17,5$ d.24i) se caracterizan por ir acompañadas de un cierto "trastorno" teológico-narrativo de los seis textos elegidos al no ser correspondidas las expectativas de los interlocutores humanos de Jesús o de los lectores o lectoras del EvJn. El "trastorno" teológico narrativo proviene de la difícil o imposible compaginación de la "eternidad-temporalidad", de que participa Jesucristo, que el no creyente es incapaz de armonizar $(6,62 ; 8,58)$, o está ocasionado por el Bautista o el evangelista, que "altera" los tiempos o niveles de la narración por motivos teológico-narrativos para despertar el interés de los oyentes o lectores/ lectoras $(1,15.30)$, o por Jesús mismo en la Oración sacerdotal en su tensa situación de esperar "ser glorificado por el Padre con la gloria que tenía junto a ti antes que el mundo existiese" (17,5d), o pidiendo que sus discípulos un día "contemplen mi gloria, la que me diste, porque me amabas, antes de la fundación del mundo (17,24i). Ciertamente los discípulos (sobre todo, el DA [= Discípulo Amado] Jn 13,23-25; 19,35; 20,2-8; 21,7.24] o el autor del EvJn [21,24]), comprenderán profundamente después de Pascua la persona de Cristo y el significado cristológico de sus palabras ${ }^{25}$.

Las afirmaciones del prólogo sobre la "preexistencia de Jesús", en cuanto el Verbo preexistente junto al Padre en el Principio $(1,1-2)$, como creador $(1,3.10)$, vida $(1,4 ; 11,25 ; 14,6)$ y luz de los hombres $(1,4-5.7-9 ; 3,19-21 ; 8,12 ; 9,5 ; 12,35-36.46)$, en cuanto Verbo encarnado e Hijo unigénito del Padre (1,14), el Preexistente (15), Jesucristo por quien nos han llegado la gracia y la verdad $(1,17)$ y Dios Unigénito, que está en el seno del Padre y es su Revelador $(1,18)$ y los títulos que aparecen a partir de Jn 1,19, especialmente (Jesús) como Preexistente $(1,30)$ junto con el del Hijo del hombre $(1,51)$, que reemplazará al título de Verbo encarnado en el corpus del EvJn, señalan y marcan el camino de Jesús en la tierra desde su encarnación hasta su muerte (19,30). En cambio, Jesús en cuanto Verbo encarnado $(1,14)$ y el Enviado

\footnotetext{
${ }^{25}$ F. Kunath, ibid., 313-314.
} 
del Padre subrayan el camino de Jesús desde el cielo a la tierra (comparar 1,1-2.14) o en dirección inversa, el camino de la tierra al cielo al morir en la cruz $(3,14 ; 6,62$; $8,28 ; 12,32.34 ; 17,5 \mathrm{~d} .24 \mathrm{i})$. Por su parte, las afirmaciones sobre la"preexistencia del Verbo" (1,1-4) destacan la divinidad y trascendencia de Jesucristo, quien con su Encarnación (1,1-2.14) trascendió el espacio y ahora en movimiento de retorno, como aparece en la Oración sacerdotal, trasciende el tiempo (comparar 17,5d.24i y $1,1-2)$.

Resumiendo, la estructura del "camino" del Hijo enviado viene dada con los verbos que significan "enviar" (ảmoбTé $\lambda \lambda \omega$ [apostél-lo: "envío"]: 3,17.34; 5,38;

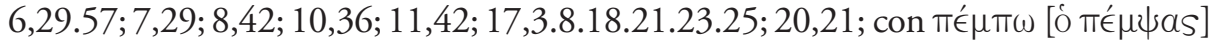
"el que me ha enviado": 4,34; 5,23.24.30.37; 6,38.39.44; 7,16.18.28.33; 8,16.18.26.29; $9.4 ; 12,44.45 .49 ; 13,16.20 ; 14,24.26 ; 15,21.26 ; 16,5.7 ; 20,21)$, lo que implica que Jesús es el Hijo de Dios, que ha venido a cumplir la voluntad salvífica del Padre. La estructura del Hijo del hombre (Jn 1,51; 3,13.14; 5,26.27; 6,27.53.62; 8,28; $9,35 ; 12,23.34 ; 13,31)$ reemplaza la del Verbo o del Logos encarnado e implica también la divinidad de Jesús. La "preexistencia de Jesús" se expresa explícitamente en las siete frases de "preexistencia de Jesús"; implícitamente se contiene en las numerosas frases formuladas con los verbos que indican "enviar". De las frases formuladas con el título "El Hijo del hombre" la frase de "preexistencia de Jesús" solo aparece en 6,62. Esto implica que el título "Hijo del hombre", que reemplaza al del Verbo encarnado, expresa la realidad de la humanidad de Jesús o su encarnación; la expresión "Hijo del hombre" excluye toda connotación de supuesto "ingenuo docetismo", que achacó E. Käsemann al cuarto evangelista ${ }^{26}$.

\section{COMENTARIO EXEGÉTICO DEL PRÓLOGO DE SAN JUAN (1,1-18)}

\subsection{Exposición de la eStRuCtura del PRÓlogo de SAN JuAN DESDE Un PUNTO DE VISTA SINCRÓNICO}

Muchos especialistas del EvJn — aunque no todos— son de la opinión de que al prólogo de San Juan subyace un himno cristológico antiguo, que tratan de reconstruir según sus puntos de vista: en la atribución de algunos versículos al pretendido

${ }^{26}$ Cf. F. Moloney, The Johannine Son of Man (BSRel 14) Rom 1976, ${ }^{21978: ~ l a ~ t e s i s ~ d o c t o r a l ~}$ de F. Moloney refuta la hipótesis del "ingenuo docetismo" del EvJn según E. Käsemann. Sobre la cuestión de si la herejía que surgió en una parte de la iglesia joánica era doceta o no, $c f$. Jean-Daniel Dubois, "Le docétisme des christologies gnostiques revisité", NTS 63 (2017) 279-304, espec. 303-304. 
himno coinciden a veces la mayoría de los exegetas, mientras que en otros el acuerdo es escaso. Soy partidario de que bajo el prólogo del EvJn subyace un himno; pero de esta cuestión trataremos en otro artículo, puesto que en este artículo es evidentemente inoportuno incluirlo por la longitud excesiva que supondría. Hoy día exige la metodología, que se distinga entre nivel sincrónico y diacrónico, dando al comienzo preferencia al sincrónico. Visto el texto del prólogo sincrónicamente aparece como una unidad, y difícilmente se encuentran aporías o dificultades insolubles. El prólogo de San Juan se divide en dos grandes partes: en la primera se habla del Verbo "no encarnado" (= äбаркоs [= ásarkos]), "que carece de naturaleza humana"27, y comprende los vs. 1,1-13; la segunda parte, que trata del Verbo "encarnado" (= "̌v [= énsarkos]) abarca los últimos versículos del prólogo (v. 14-18). Aunque esta división es clara y no cabe duda alguna en ella, podemos subdividir esta primera parte en dos: $a)$ 1,1-5 y b) 1,6-13. O sea, concretamente el prólogo de San Juan queda subdivido en tres partes: $a)$ en la primera parte $(1,1-5)$ el Verbo "no encarnado" es el protagonista, del cual se destaca su preexistencia antes de todos los siglos junto al Padre (ad intra: hacia adentro de la divinidad) (v. 1-2) y (ad extra) se subraya la creación del mundo (v. 3), su actividad conservadora e iluminadora en favor de los hombres (v. 4) y la reacción negativa de las tinieblas a su acción iluminadora (v. 5). Desde el punto de vista exegético-teológico los motivos de 1,1-5 son semejantes a los del relato del Génesis ("principio", "palabra", "crear", "luz" y "tiniebla") y al tema de la sabiduría del AT.

b) En la segunda parte, aparece de repente Juan el Bautista, el testigo del Verbo, al principio del párrafo, pasando el Verbo aparentemente por poco tiempo a segundo término (6-8), para volver a ejercer su protagonismo iluminador y decisivo para todo hombre, para el mundo y el pueblo judío, aunque hayan fracasado muchos (9-11); pero no todo ha sido fracaso, porque algunos le recibieron, y creyeron en él, a los que dió el poder de ser hijos de Dios (12-13). También los motivos de estos versículos se asemejan a los de la Sabiduría del AT ("luz", "creación del mundo por el Verbo o Sabiduría", "venida a los suyos que no le reciben”; el poder de ser hijos de Dios", por una "nueva generación" [v. 12-13]). En este párrafo la presencia y preexistencia iluminadora del Verbo en el mundo (v. 9) y su actividad creadora salvadora en la historia del AT (v. 10-11) se asemeja a la de Cristo en el desierto, de la que habla San Pablo (1 Cor 10,1-6). Pero el Verbo en esta segunda parte no es aún el Verbo encarnado, sino el ásarkos que prefigura el Verbo encarnado, del que se habla a continuación. c) En la tercera parte $(1,14-18)$ el prólogo alcanza su punto culminante: la encarnación del Verbo, que se convierte, por así

${ }^{27}$ Cf. Diccionario griego español III, Madrid (CSIC) 1991, 549. 
decir, en verdadero ciudadano o hermano nuestro $(1,14 b)$ e irradia su "gloria como la del Unigénito del Padre" (1,14cde). Juan Bautista, que fue presentado a los oyentes o lectores o lectoras en 1,6-8, aparece en 1,15 como si no estuviera aún bien colocado en el tiempo y espacio de la historia salvífica concreta, —a diferencia de 1,30—, proclamando la Preexistencia del Verbo encarnado (v. 15). En este momento parece como si la comunidad creyente del Verbo encarnado juntase su voz a la de Juan (cf. 1,14bcde.16.17) para pregonar que ha visto la gloria del Unigénito del Padre, lleno de gracia y verdad (v. 14cde), la gracia y la verdad (que) nos han llegado por medio de Jesucristo (17b). También aquí resuenan motivos de la misericordia de Yahvé en el AT, pero sobre todo en Éx 34,6 (cf. Sal 25,10; 40,11; 85,11). El prólogo concluye y se cierra con la rotunda afirmación que "nadie excepto el Dios Unigénito, que está en el seno del Padre, ha visto a Dios" (1,18ab), a la vez que se alcanza el nivel del principio: "En el principio existía el Verbo y el Verbo estaba junto a Dios y el Verbo era Dios". Este estaba en el principio junto a Dios (1,1-2). Con la última afirmación "... aquel (el Verbo) es quien lo ha dado a conocer" comienza la revelación de Cristo que narra el EvJn.

2.2. Comentario exegético - teológico: la Cristología del Verbo en el PRÓLOGO (1,1-18)

2.2.1. El Verbo en su relación personal hacia dentro ("ad intra") con el Padre (1,1-2); el Verbo y su actividad creadora "hacia afuera" ("ad extra" [1,3]); como venero insondable de Vida e inteligibilidad o Luz de los hombres $(1,4)$ y su relación con la tiniebla $(1,5)$

\subsubsection{Relación del Verbo con Dios Padre $(1,1-2)$}

La primera frase del prólogo de San Juan: "En el principio existía el Verbo" $(1,1 a)$ contiene una referencia clara, intencionada a Gén 1,1 , que resulta más evidente, si se compara el texto joánico con la versión griega de Gén 1,1 de los Setenta [= LXX]), pero mucho mayores que las coincidencias son las diferencias entre el prólogo de San Juan y los primeros versículos del Génesis ${ }^{28}$. Efectivamente, el que

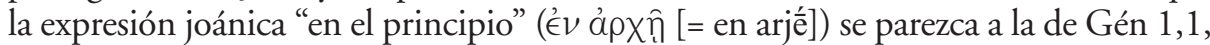
y esté colocada como la de Gén 1,1 al comienzo del EvJn 1,1 así como el que la actividad creadora del "Logos" joánico por medio del cual fueron creadas todas las cosas se asemeje a la palabra creadora del Gén 1,1, son razones suficientes y convincentes

${ }^{28}$ Cf. E. Haenchen, Johannesevangelium. Ein Kommentar, Tubinga (Mohr- Siebeck) 1980, 115. 
de que el autor joánico se inspiró en Gén 1,1-3. Pero el evangelista no quiere solo dar una interpretación profundizada de Gén 1, 1, según la cual Dios ha creado el mundo por su "palabra", — de lo que hablará más tarde en 1,3—, sino que aspira a elevarse al "principio absoluto" (= Ł́ $\mathcal{a} \rho x \hat{n}[=$ en arjé] $)$, anterior a la creación, no nombrando en primer lugar a Dios sino al Logos o al Verbo. Es en efecto extraño que el evangelista del EvJn o el autor del himno joánico no comience nombrando a Dios (Padre) y la creación, como en Gén 1,1 griego LXX; "En el principio creó Dios el cielo y la tierra", sino al Verbo: "En el principio existía el Verbo" (Jn 1,1a). El Verbo es ensalzado tan en alto que parece escandaloso. Tolerable se hace, sin embargo, esa afirmación por las puntualizaciones siguientes del evangelista: "Y el Verbo estaba junto a Dios y el Verbo era Dios" (Jn 1,1bc) ${ }^{29}$. Ya el judaísmo advirtió que la palabra de Dios es indefectiblemente eficaz, o sea, que hace lo que significa, y que Dios ha creado el mundo por medio de su palabra: "Dijo Dios ..." (Gén 1,3.6.9, etc.).

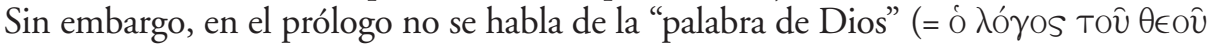
[ho lógos tu zeú]), como en Ap 19,13, sino simplemente del "Verbo" (= ó $\Lambda$ ó El evangelista tiende de verdad a una cristología más elevada que la del Apocalipsis. El artículo delante de la palabra "Verbo" indica que los oyentes o lectores o lectoras del EvJn sabían que el título "el Verbo" se refería a "Jesucristo" $(1,17)$. Las connotaciones filosófico-religiosas del título "el Logos o el Verbo" son díficiles de deducir ${ }^{30}$. La frase con que comienza el prólogo: "En el principio existía el Verbo" (Jn 1,1a) hace pensar en especulaciones judías acerca de la Sabiduría, que, sin embargo, no hablan de la "palabra de Dios", sino de la Sabiduría (Prov 8,22-23; Eclo 24,9). En esas especulaciones sapienciales anticotestamentarias no se habla nunca del "Logos o el Verbo"31. Es impresionante que el judaísmo haya comprendido que la palabra de Dios proviene de la inmaterialidad divina, es decir, de su altísimo entendimiento divino, por lo cual emplea la expresión "Sabiduría" ( Sabiduría de la Biblia hebrea fue continuada por el judaísmo helenista, especialmente por Filón de Alejandría (que nació hacia la mitad del siglo I d.C.), quien ciertamente ya habla del "Logos" casi medio siglo antes del EvJn. En el fondo los conceptos "palabra", "Sabiduría" y "Logos" son afines. Puesto que Jesús no fue mujer sino hombre, el evangelista eligió el título "Logos"

${ }^{29}$ Cf. ibid., 116.

${ }^{30}$ R. Schnackenburg I, “Die Herkunft und Eigenart des joh.Logos-Begriffs”, 257-269. F. Kunath, ibid., 335-340, ha actualizado el material filosófico-religioso de la palabra "Logos" a base del artículo de J. Frey, "Between Tora and Stoa, How Could Readers Have Understood the Johannine Logos?", en: Jan van der Watt, R. Alan Culpepperund Udo Schnelle (eds.), The Prologue of Gospel of John. Literary, Theological and Philosophical Contexts; Papers Read at the Colloquium Ioanneum 2013 (WUNT), Tubinga (Mohr Siebeck), 186-231. A mi parecer, no ha conseguido cambiar la situación.

${ }^{31}$ Cf. Claudia Sticher, "Frau Weisheit hat ihr Haus gebaut. Alttestamentliche Anknüpfungspunkte der johanneischen Logos-Christologie”, en: Johannesprolog (cf. nota 1), 27-47, espec. 31-32.40-46.

${ }^{32}$ Cf. C. Sticher, ibid., 46-47. 
Del Verbo, que es siempre sujeto en Gén 1,1, se hacen tres afirmaciones: en primer lugar, que existía "en el principio", "antes de la creación del mundo"; en segundo lugar,que es una persona "absoluta", es decir, que no depende de nada creado, "exenta de toda relación creada, no solo del mundo sino de todo ser que no sea Dios mismo", p. ej., del demonio, "del príncipe del Mundo", del que se habla en el EvJn $(1,5 ; 1,70 ; 8.44 ; 12,31 ; 13,2 ; 14,30 ; 16,11)$; en tercer lugar, se afirma del Verbo que es "eterno", fuera del tiempo, antes de la creación del mundo. En el AT no se predican esos atributos de la Sabiduría, que es creada, pues son propios y exclusivos del Verbo joánico increado como el Padre. La forma verbal "existía" (= ク๊ [ēn]) califica la existencia del Verbo de duradera y permanente y, al mismo tiempo, implica el pasado, desde el punto de vista del evangelista, que mira desde su presente a la preexistencia del Verbo. La segunda aseveración: "Y el Verbo estaba junto a Dios"

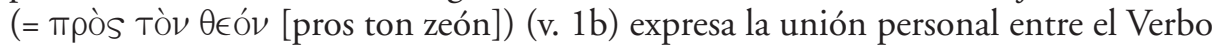
y Dios (Padre). Dios no es un Dios solitario sino intrínsecamente sociable y comunicable. Si en Jn 1,1a se ha afirmado la existencia del Verbo, anterior a todo ser creado $\mathrm{y}$ al mundo, ahora en el 1,1b se destaca su relación personal respecto al Padre, naturalmente anteriormente a la creación. Es equivocado imaginarse a Dios Padre como si fuese anterior al Verbo o al Hijo, o al Verbo como posterior en el tiempo: ni el Hijo o el Verbo es posterior al Padre ni el Padre es anterior al Verbo; podríamos decir que el Padre es tan joven como el Verbo y el Verbo como el Padre o el Espíritu Santo a pesar de que existen una eternidad: ninguna de las tres personas divinas es a este respecto anterior o posterior a la otra, porque "en el principio", antes de la creación, no existía el tiempo, sino la eternidad. En este v. 1,1b se afirma claramente la diferencia de las personas divinas. Para Filón de Alejandría las palabras griegas "Dios sin artículo (= $\theta \epsilon o ́ s$ [= zeós]) en sentido predicativo, y "el 'único Dios' verdadero de la fe monoteísta judía" con artículo ó $\theta \in o ́ s$ ” no son idénticos (cf. Filón, De somniis I,

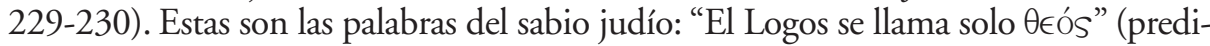
cativamente: "dios"), "pero no $\delta \theta \in$ cós" (= "el único Dios" según la fe monoteísta judía), "porque "el Logos" no es "dios" en sentido propio, aunque se predique de él que es

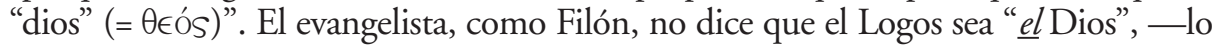
que para un judío ortodoxo monoteísta sería engañoso, falaz e incluso blasfemo-, pues "al Logos o al Verbo" no le designan los judíos helenistas nunca con la expresión griega ó $\theta \in o ́ s$ ( = "el Dios"), como hemos oído decir a Filón, ya que significaría convertir al "Logos o al Verbo"en "el Dios único" de los judíos. Esta expresión, en cambio, la reservan el evangelista y los cristianos a Dios Padre, la primera persona de la Ssma. Trinidad. Los judíos como Filón la refieren monoteísticamente al "unico Dios". Si Filón, en cambio, designa al "Logos" con la palabra $\theta \in o ́ s$ (= "Dios" [sin artículo]), lo entiende referido al "Logos" impropiamente, el evangelista y los cristianos, en cambio, lo entienden en sentido propio: El Verbo es propia y realmente Dios como el Padre. Los autores inspirados y todos los cristianos no confunden las personas, y cada una de las personas es verdaderamente "Dios", como lo es también el Espíritu Santo. Ni rebajan de categoría divina al Verbo: ambas personas, incluída la del Espíritu Santo,son igualmente divinas o simplemente "Dios". El Padre es Dios, el Verbo es Dios y el Espíritu Santo es también "Dios", pero no son propiamente tres dioses sino tres personas en un solo "Dios" o en una sola esencia divina. De hecho, 
tanto para el evangelista, autor del prólogo, como para el autor del himno que subya-

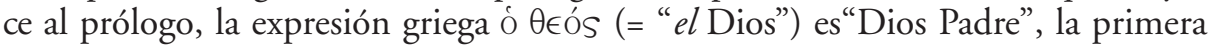
persona divina de la Ssma. Trinidad, a quien el evangelista llama el único Dios verda-

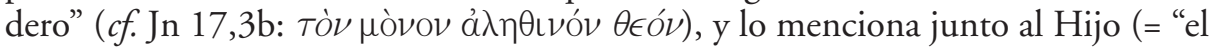
Verbo encarnado"): “... y a tu enviado, Jesucristo" (17,3c), que es en 1,18a "Dios Unigénito" (lectura que prefiere Nestle-Aland) o "Hijo Unigénito" (lectura menos probable), que expresa también la condición divina del Verbo o Jesucristo. Hasta aquí estamos de acuerdo con E. Haenchen, pero no así con su concepto "subordinacionista" del Verbo joánico, aunque, a renglón seguido, dice E. Haechen que el autor joánico solo insinúa el subordinacionismo, interpretando incorrectamente a Jn 14,28: “... porque el Padre es mayor que yo". E. Haenchen rebaja, a renglón seguido, el subordinacionismo de la cristología joánica en Jn 1,1, porque, según E. Haenchen, el evangelista quiere subrayar en Jn 1,1 más la comunidad o unión de las personas del Dios Padre y del Verbo que su separación o independencia ${ }^{33}$.

No es seguro si la preposición griega $\pi \rho \mathrm{s}^{-}$(= pros) significa en este lugar "junto a" (o sea: "en donde" [dativo locativo]) o si expresa un aspecto direccional de la persona del Verbo respecto a Dios Padre en el sentido de estar orientado "hacia Él"34. El Logos o el Verbo no reemplaza a la persona de Dios Padre, sino que vive en unión personal con el Padre y vive de esa relación personal comunitaria, como se afirma en el último versículo del prólogo $(1,18 \mathrm{~b})$ y en otros lugares del EvJn $(4,34)$. El final del v. 1c "Y el Verbo era Dios" subraya aún más la importancia de la compenetración interpersonal y unión de las personas divinas antes de ser creado el mundo: El Logos era de la esencia de Dios Padre. La primera afirmación del prólogo atribuyó al Logos o al Verbo lo máximo que se puede pensar, o sea, la existencia en el principio antes de la creación $(1,1 \mathrm{c})$; al final del versículo afirmando que el Verbo era Dios1,1c aclara y recalca esa misma dignidad divina, mientras que la afirmación intermedia sobre la relación personal del Logos con Dios Padre $(1,1 b)$ pone de relieve la relación del Logos orientada hacia Dios Padre, relación que es la vida por antonomasia. La concatenación quiástica de las tres frases de Jn 1,1abc en la forma aba’ desaconseja la opinión de E. Haenchen sobre la cristología subordinacionista, y elimina los resabios subordinacionistas. En efecto, la concatenación de Jn 1, labc,

${ }^{33}$ Cf. E. Haenchen, ibid., 116.

${ }^{34}$ La mayoría de los exegetas opina que la preposición griega en cursiva $\pi \rho \grave{s}$ Tòv $\theta \in$ (= "junto a” Dios) ha perdido en el griego del NT o Koiné el significado dinámico del griego clásico; sin embargo, hoy día hay autores que con buenos argumentos sostienen la connotación dinámica de la preposición griega: $c f$. Hans Weder, Ursprung im Unvordenklichen (BThSt 70), Neukirchen-Vluyn (Neukirchener) 2008, 32 y nota 12, que afirma que "el Logos estaba orientado siempre hacia Dios (Padre); su orientación y cercanía a Dios Padre es la relación de vida por excelencia”; J. Beutler, Das Johannesevangelium, ( $c f$. nota 9) 83: "El Logos ...desde toda la eternidad orientado al Padre (esto expresa la preposición griega $\pi \rho \grave{s}$ )", siguiendo a Ignace de la Potterie. 
según la cual el Logos aparece en relación con Dios Padre induce a desistir de una cristología subordinacionista hacia la que se inclina E. Haenchen, según el cual "una segunda esencia divina independiente debe aparecer junto al supremo Dios" ${ }^{35}$. Si el evangelista hubiera profesado una cristología subordinacionista, quien elige sus palabras con tanto esmero, no hubiera debido escribir $\theta \in o ́ s, ~ s i n o ~ \theta \in i ̂ s$ (= zeios [= divino"]). Es decir, no se afirma en Jn 1,1 que Dios y el Verbo sean idénticos, como, en dirección opuesta a E. Haenchen, sostiene R. Bultmann ${ }^{36}$, quien con su desmitologización niega la diferencia personal entre Dios Padre y el Logos, pero tampoco que Dios Padre y el Verbo sean dos personas relativamente independientes, como defiende E. Haenchen. Aunque R. Bultmann rechace la definición del Concilio calcedonense: "dos naturalezas distintas unidas en la persona divina" del Verbo, que es "verdadero Dios y verdadero hombre, hay que reconocer, sin embargo, que Bultmann ha observado correctamente que Dios Padre desde toda la eternidad se ha expresado o agotado completamente en el Logos, su Palabra, y que no existe Dios Padre sin su Logos, pero el exegeta de Marburgo no ha advertido la distinta personalidad propia de las correspondientes personas divinas. Como ya hemos dicho, Haenchen y Bultmann van en direcciones opuestas: Mientras Bultmann subraya la identidad de Dios y el Logos, Haenchen, en cambio, acentúa la diferencia entre Dios y el Logos, y parece tender hacia la subordinación del Logos bajo el Dios supremo, "en el que el creyente puede ver al Padre precisamente porque el Hijo no quiso hablar sus propias palabras, ni realizar sus propias obras, ni quiso hacer su propia voluntad, sino solo (es) su palabra, su obra y la voluntad del Padre". M. Theobald quiere clarificar en qué medida E. Haenchen es subordinacionista", si es que lo es. Tal vez es que

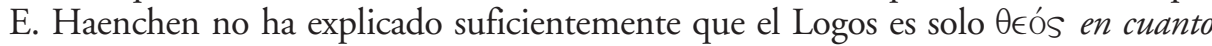
vive del único y supremo Dios (ó $\left.\theta \in \epsilon_{S}\right)^{\prime \prime}{ }^{37}$.

El v. 2 confirma las afirmaciones anteriores sobre el Verbo. Es interesante que se vuelvan a tomar las expresiones "en el principio" y "junto a Dios", pero no aparezcan más ni la palabra "Dios", ni el título "el Logos". Este no se repite en este segundo

${ }^{35}$ Michael Theobald, Im Anfang war das Wort. Textlinguistische Studie zum Johanesprolog (SBS 106), Stuttgart 1983, 43-44.45.

${ }^{36}$ R. Bultmann, Das Evangelium des Johannes, Gotinga (KEK II [Vandenhoeck -Ruprecht]) $\left.{ }^{18} 1964\right)$ 17: "El Logos es por tanto equiparado con Dios". Udo Schnelle, Das Evangelium nach Johannes, Leipzig (ThHK [Evangelische Verlagsanstalt]) 1998, 31, contradice la opinión de Bultmann: "El Logos no es simplemente idéntico con Dios".

${ }^{37}$ Cf. E. Haenchen, Das Johannesevangelium (edit. U. Busse), Tubinga 1980, 117-119; Michael Theobald, Im Anfang war das Wort (cf. nota 35) 42-47. Habría que pedir a Theobald que explicase qué entiende por "vivir del único y supremo Dios" y que se preguntase en qué medida las categorías filosóficas y teológicas que suenan a modernas están de acuerdo con las de los primeros concilios de la Iglesia, especialmente los de Nicea, Niceno-Constantinopolitano y Calcedonia. Los exegetas tendrían que preguntarse, qué filosofía y teología están detrás de su trabajo exegético. Esta pregunta me ha venido a la mente al estudiar la tesis de Friederike Kunath, Die Präexistrenz Jesu, anteriormente citada, y que, a pesar de ser luterana, ha repasado los concilios mencionados. 
versículo; volverá a aparecer por segunda y última vez en 1,14. Logos queda sustituido por el pronombre demostrativo "este" (= oûTos [utos]). La repetición recalca que el anteriormente mencionado Logos que pertenecía a la esencia del único Dios existía en el principio junto a Dios. Estructuralmente se observa una referencia a 1,18: "A Dios nadie le ha visto, el Unigénito, que (es) Dios, que está en el seno del Padre, es quien lo ha dado a conocer".

\subsubsection{Relación del Logos o Verbo respecto a la creación (v. 3)}

El v. 3 contiene afirmaciones que se refieren a la creación del mundo por medio del Verbo: "Por medio de él se hizo todo, sin él no se hizo nada de cuanto se ha hecho". Todo (= Távta [neutro plural]) sin artículo no significa solamente en general todas las cosas, sino más aún, todas y cada una en particular y en concreto; es decir, nada de lo que existe, ha existido o existirá, se escapa, se ha escapado o se escapará indemne del poder creador del Verbo. A esta afirmación corresponde la últi-

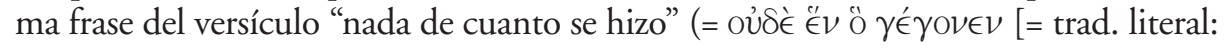
"ni siquiera una sola cosa que ha venido a la existencia y permenece en ella]), y sirve para recalcar la omnipotencia creadora del Verbo. Es una cuestión en la que no se ha llegado a un total acuerdo si el v. $3 \mathrm{c}$ pertenece al v. $4 \mathrm{o}$ al v. $3 \mathrm{ab}$. Me inclino por la opinión de los que opinan, a mi parecer, con mejor argumento exegético-teológico que el v. $3 \mathrm{c}$ ha de juntarse por razones exegético-teológicas a los vs. $3 \mathrm{ab}^{38}$. Esta correspondencia entre el principio (v. 3a: "por medio de él se hizo todo) y el final (v. 3c: "ni siquiera una sola cosa que se ha hecho") es un argumento más para unir v. $3 \mathrm{c}$ con los vs. 3ab. En el himno cristiano de Col 1,16 encontramos afirmaciones sobre la creación: "Porque en él fueron creadas todas las cosas. celestes y terrestres, visibles e invisibles, Tronos y Dominaciones, Principados y Potestades; todo fue creado por él y para él'. Tanto el autor del prólogo de San Juan como el del himno de Col 1,15-17 quieren decir que no hay nada que quede fuera del poder de Dios. También "el príncipe de este mundo" le está sometido $(12,31 ; 14,30 ; 16,11)$, y no está fuera del poder omnipotente del Verbo.

¿Cómo hay que interpretar la mediación del Verbo en la creación? La explicación más convincente es la siguiente: Puesto que el Verbo es Dios por esencia, el Verbo ha actuado en la creación como concausa eficiente personal con Dios Padre. Ahora bien, por ser la creación del mundo obra conjunta de toda la Ssma. Trinidad, operan las tres personas juntas al mismo nivel y rango, aunque la acción y el efecto se atribuyan especialmente a una, como aquí al Verbo, por ser esta la persona que

${ }^{38}$ Por razones exegético-teológicas es preferible juntar v. 3c a 3ab, y no a v. 4ab: $c f$. R. Schnackenburg I, 216-217. 
se encarnará y será mediadora entre el mundo y las demás personas divinas. Dado que los vs. 1,1-3 muestran influjo del AT ( $c f$. espec. Gén 1,1ss.), se ha de entender la expresión "por medio de él" ( $\delta \iota^{\prime}$ ' aủTô̂) no solo como causa ejemplar sino principalmente como causa eficiente personal. El Verbo en cuanto persona y como Dios de esencia igual a la del Padre ( $c f$. v. 1 ) interviene activamente y actúa inmediatamente en la creación.

Así como las afirmaciones de los vs. 1-2 acerca del Verbo sirven para fundamentar la exclusividad de su revelación ( $c f$. v. 18), asimismo las afirmaciones sobre la creación en el v. 3 expresan que la palabra del Verbo alcanza inevitablemente a cada hombre, porque toda la creación, incluido el género humano, debe al Verbo su origen y su ser.

\subsubsection{La relación del Verbo con respecto al mundo de los hombres (v. 4-5)}

Si en el v. 3 el objeto de la actividad creadora del Verbo consistía en otorgar a toda la creación en general la existencia, ahora en el v. 4 la finalidad de su actividad es regalar a su parte más importante, es decir, al mundo de los hombres, la vida y la revelación divina. El v. 4 reza así: "En él había vida $(=\zeta \omega n ́$ [= dsōế]) y la vida era la luz de los hombres". En primer lugar, en el v. 4a "vida" carece de artículo, porque se refiere a la vida divina por excelencia del Verbo (ad intra [= hacia adentro]), que ya habíamos sospechado en la relación personal del Verbo hacia el Padre ( $c f$. v. 1b "... y el Verbo estaba junto al Padre"). Esta vida divina se caracteriza por su originalidad y plenitud, que se semeja a un manantial inagotable de agua pura. En ese sentido dice Jesús: "Como el Padre tiene vida en sí, así también le ha dado al Hijo tener la vida en si'” $(5,26)$. Esta vida divina se refiere primeramente al Verbo, en el cual tiene su origen la fuerza infinita de la que brota la vida. En la segunda parte del v. $4 \mathrm{~b}$ se escribe la vida" (con artículo) y se refiere a la vida del Verbo "que se irradia hacia fuera para convertirse en "la luz de los hombres". La "vida" otorgada por el Verbo, que deviene en "la luz de los hombres, no significa simplemente "el ser" o "cualquier clase de vida". Se trata en primer lugar de la vida intelectual, que solo el hombre puede recibir a diferencia de los demás seres faltos de razón, y de modo especialísimo de la vida sobrenatural. La razón de por qué el Verbo o el Jesús histórico tiene en sí esa vida divina o fuerza que da la vida, es, por una parte, porque el "Verbo era Dios" y "en el principio estaba junto al Padre" (v. 1-2), y, por otra, porque es el creador (v. 3). Esta fuerza del Verbo que crea vida abarca no solo la vida religiosa-espiritual conforme a la naturaleza del hombre sino también la vida sobrenatural que excede la vida natural, que hace a los hombres hijos de Dios (cf. 1,12-13).

La vida que se encuentra en el Verbo en toda su pureza original como en un manantial inagotable y en toda su plenitud es definida como la luz de los hombres. Esas dos palabras relacionadas entre sí "vida y luz" apuntan respectivamente en dos sentidos o direcciones distintas a pesar de su estrecha trabazón: "vida" a la que se refiere aquí por primera vez el prólogo es la causa primordial, fundamento de toda vida, mientras que "luz" significa para el hombre el aspecto iluminador y orientador de la fuerza vital divina. Luz y vida son conceptos e imágines para expresar la revelación 
y la salvación anunciadas por el evangelista que han tomado forma concreta en el Verbo encarnado. Estos dos conceptos "vida" y "luz" aparecen frecuentemente en el AT, sobre todo, en los salmos y en la literatura religiosa, no bíblica ${ }^{39}$. Lo propio y específico que distingue el pensamiento cristiano de aquel del AT y del religioso no bíblico consiste en que esa realidad por excelencia "luz-vida" ha tomado forma concreta en Jesucristo $(1,14.16-17)$. No carece de interés la cuestión cuánto tiempo duró la actividad reveladora e iluminadora del Verbo respecto al mundo de los hombres antes de su caída ${ }^{40}$. Ciertamente no se puede limitar a la época del paraíso, ya que ni en el prólogo, ni en el EvJn se menciona el paraíso. La forma verbal "era" (= ク̉ [ [ến]) expresa de por sí duración indefinida, que naturalmente puede ser limitada por adverbios de tiempo. Pero el plan de Dios con motivo de la creación era que los hombres por la actividad del Verbo se convirtiesen en hijos de Dios.

El v. 4 se refiere en primera línea aun a la revelación del Verbo antes de su encarnación, o sea, al Verbo ăбapкоs (= ásarkos [no encarnado]). Lo que debía ser el Verbo para el intacto género humano, pero quedó sin realizarse por el pecado original, se convertirá en la realidad gracias a Jesucristo ( $c f$. v. 14.16-17): El Verbo se ha convertido en luz y vida de los hombres: "Yo soy la luz del mundo; el que me sigue no camina en tinieblas, sino que tendrá la luz de la vida" $(8,12)$. Que luz y vida son pensamientos muy importantes del EvJn se ve en el hecho de que no solo al principio del EvJn se cita un dicho de la luz sino que el cap. 9 comienza con otro dicho de Jesús sobre la luz que tiene carácter simbólico y programático: "Mientras estoy en el mundo, soy la luz del mundo" $(9,5)$. A continuación tiene lugar la curación del ciego de nacimiento y recibe la fe (v. 38). En el relato de la resurrección de Lázaro se presenta Jesús como el donador de la vida: "Yo soy la resurrección y la vida; el que crea en mi, vivirá...” $(11,25)$.

Aparecía en Jn 1,4 el mundo aún intacto, ahora nos encontramos en primer plano en el v. 5 con el mundo que se ha alejado de Dios, que recibe el nombre de tiniebla (= бкотía [skotía]). Hasta ahora predominaban los imperfectos (seis referidos al Verbo), además, dos aoristos referidos también al evento de la creación y un perfec-

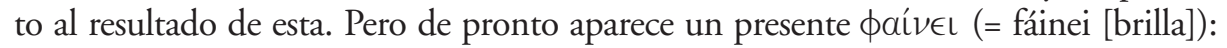
"Y la luz brilla en la tiniebla, y la tiniebla no la recibió" $(1,5)$. La forma del presente de indicativo "brilla" se refiere a la revelación de Jesús, que dura desde antes de su encarnación hasta el tiempo en que escribe el evangelista el EvJn y su comunidad anuncia el evangelio de Jesús. El sentido de la segunda parte de $1,5 \mathrm{~b}$, que la nueva versión de la CEE traduce "Y la tiniebla no lo recibiô" (кат́́ $\lambda \alpha \beta \in \nu$ ) es más probable: a) el término бкотía (= skotía [tiniebla]) no alude aquí al mundo de las fuerzas

\footnotetext{
${ }^{39}$ Cf, R. Bultmann, Johannesevangelium, 22-26; R. Schnackenburg I, 219-220.

${ }^{40}$ No es necesario advertir que ni el prólogo, ni el EvJn hablan de los ángeles, sino solo de la "vida como luz de los hombres".
} 
cósmicas del caos primordial mítico, con el que armonizaría bien el motivo de que la luz no fue subyugada por las fuerzas del abismo sino que se refiere al mundo de los hombres; b) el significado de "no recibió" (= oủ кaTé $\lambda \alpha \beta \in \nu$ [= u katélaben]) es semánticamente semejante a "no conoció" (oủk É $\gamma \nu \omega$ [uk egnō] v. 10) y "no reci-

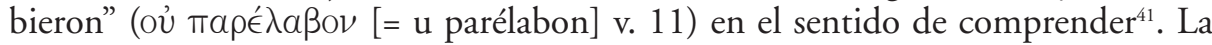
mayoría de los padres griegos, siguiendo a Orígenes, y también bastantes exegetas modernos, sobre todo de habla inglesa, traducen: "Y la tiniela no oprimió, venció, subyugó la luz" ${ }^{2}$. El mundo se ha constituido en mundo por su rechazo de Jesús, el revelador del Padre; su repulsa de Jesucristo, el enviado del Padre, convierte la falta de fe y la incredulidad en grave pecado: "Si yo no hubiera venido y no les hubiera hablado, no tendrían pecado, pero ahora no tienen disculpa para su pecado. El rechazo del Revelador, enviado del Padre, tiene graves consecuencias para el mundo. Pero la luz a pesar de la oposición seguirá adelante. En la primera carta de Juan dice el autor: "Pues la tiniebla pasa, y la luz brilla ya" (1 Jn 2,8). Brilla en la comuniad joánica; la fuerza misionera del mensaje de Jesús continúa ofreciendo al mundo con su predicación y testimonio la revelación divina. En los escritos de Qumrán se habla mucho de "luz" y "tiniebla", pero la comunidad no se atreve a entablar relación con el mundo porque le falta el empuje misionero ${ }^{43}$. A partir del v. 5 las afirmaciones del prólogo comienzan a referirse al Jesús histórico o encarnado (= Ł้ aunque el Verbo no se haya encarnado aún, el evangelista le presenta ya actuando como encarnado, aunque la encarnación se menciona por primera vez en 1,14. En el himno prejoánico, los vs. 9-11 se referían probablemente al Verbo no encarnado.

\subsubsection{El testimonio de Juan el Bautista que anuncia a Jesucristo (v. 6-8)}

A Juan el Bautista no se le llama en el EvJn Bautista, como en los Sinopt (Mt 3,1, 11,11.12; 14,2.8; 16,14; 17,13; Mc 6,25; 8,28; Lc 7,20.33; 9,19), pero sí se menciona su actividad bautista, que proviene de la tradición sinóptica (Jn 1,25-26. 28.31.33) o de otras fuentes ( $c f .3,23.25-26$ y 4,1; 10,40), si bien carece de importancia. Su misión consiste en dar testimonio a favor de Jesús como revelador y de su misión divina: Juan "vino como testigo, para dar testimonio de la luz, para que todos creyeran por medio de él. No era él la luz, sino el que daba testimonio de la luz" (v. 7-8). Dar testimonio tiende sin excepción a promover la fe; la fe sin testimonio o no es verdadera fe o es una fe insuficiente e imperfecta: "Esto dijeron sus padres por miedo a los judíos, que habían ordenado ya expulsar de la sinagoga a todo el

${ }^{41}$ R. Schnackenburg, Das Johannesevangelium I, 222-223, sigue esta opinión; también así, aceptando los argumentos de Schnackenburg, M.Theobald, Im Anfang war das Wort, 50-51.

${ }^{42}$ Cf. Bauer-Aland, Wb, 839. H. Weder, Ursprung im Unvordenklichen, 51-52 se muestra indeciso, no se decide por ninguna de las dos opiniones.

${ }^{43}$ Cf. R. Schnackenburg I, 222-226. 
que lo confesase como Mesías ... " (cf. 9,22-23); "Incluso muchos de los principales creyeron en él, pero, a causa de los fariseos, no le confesaban públicamente para no ser expulsados de la sinagoga, pues prefirieron la gloria de los hombres a la gloria de Dios" (12,42-43). La verdadera, perfecta fe exige el testimonio (1,34; 6,66-69). El Espíritu Santo llevará a los discípulos a la confesión valiente (15,26-27; 16,7-9). A su vez el testimonio de fe suscitará en los destinatarios la fe" $(3,11)$. El testimonio de Juan tendía a que todos viniesen a la fe por su medio. Parece extraño que la misión de Juan consistiese en que "todos".(= Tá $\nu T \in S$ [pantes]) vinieran a la fe por medio de él. Aquí hay que distinguir: según la tradición sinóptica es Juan el Bautista el único de sus coetáneos que reconoció a Jesús de Nazaret como el Mesías e Hijo de Dios. Como el último profeta del AT debía mover a todos los judíos a la fe en Jesucristo como Mesías e Hijo de Dios. Pero el "todos" (= $\pi \alpha ́ \nu T \in S$ [pantes]) excede y supera la situación histórica de Juan el Bautista, pues el horizonte de su testimonio histórico no se limita a la nación judía, sino que se extiende al mundo entero y a todas las generaciones futuras. En realidad, el testimonio de Juan según el EvJn no es su testimonio histórico de entonces sino el testimonio del anuncio de la fe joánica: en la revelación de Jesús y de la Iglesia se expresa su misión divina y la exigencia universal de que todos los hombres crean en él. En el v. 7c se advierte la intención del evangelista de subordinar Juan Bautista al revelador Jesús de Nazaret o al Verbo encarnado. La polémica entre los discípulos de Juan que le tenían por superior a Jesús y a la Iglesia cristiana aparece ya en este lugar. Numerosos lugares del EvJn se refieren a este conflicto (1,6-8.15.19-36; 3,22-30; 4,1; 5,33-36; 10,40-42). Sin embargo, a pesar de ese conflicto, la Iglesia primitiva reconoció a Juan como testigo auténtico de Jesús.

\subsubsection{El rechazo del Verbo encarnado por el mundo y acogido por los creyentes (v. 9-13)}

\subsubsection{Jesucristo, el revelador del Padre, que ha aparecido en la historia humana, es la verdadera luz que ilumina a todo hombre (v. 9)}

El v. 9 repite las afirmaciones anteriores sobre el Verbo (v. 4-8), precisan-

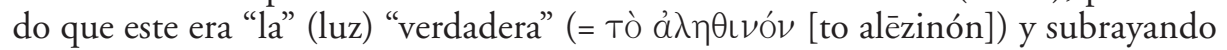

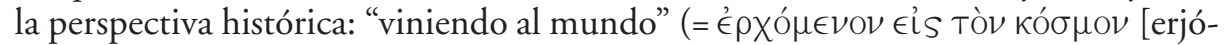
menon eis ton kosmon]). El adjetivo "verdadero" expresa una connotación negativa respecto a falsos dioses y falsas revelaciones, rechazándolos; incluso rechaza una falsa interpretación de la figura del Bautista. En cambio, la expresión "la luz verdadera" tiene un significado positivo como la luz "incomparable, cuya eficacia iluminadora proviene de su divinidad $(c f .1,1 \mathrm{c})$, que puede y tiene que manifestarse en cada persona que quiere alcanzar su fin” ${ }^{4}$. Tanto la probable adición del evangelista "viniendo

${ }^{44}$ Cf. R. Schnackenburg, I, 230. 
al mundo" (v. 9c), que se refiere al Verbo, no a toda persona que viene al mundo, así como las afirmaciones anteriores sobre el Bautista se refieren al incomparable poder iluminador del Verbo encarnado. Lo que se refería en el himno prejoánico (v. 9ab)

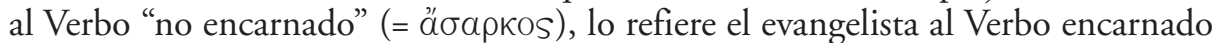
(= " modal: "Era la luz verdadera que con su venida al mundo ilumina a cada hombre". La actividad del Verbo encarnado consiste en "iluminar" (= $\phi \omega \tau i \zeta \zeta \in \nu$ [fōt-idsein: viene de luz]) a cada hombre. "Iluminar" era una actividad propia Verbo "no encarnado (= äбаркоS) en el himno prejoánico, y sigue siendo ejercida por el Verbo encarnado (3,19-21; 8,12; 9,5; 12,35-36.46). Esta misión tanto del Verbo no encarnado como del encarnado consiste en irradiar el amor divino, no solo natural o racional sino, sobre todo, sobrenatural que excede la naturaleza humana.

\subsubsection{El rechazo del Verbo hecho hombre por los hombres pertenecientes al mundo (v. 10-11)}

El кó́ros (= kosmos) o mundo de los hombres no es idéntico con el universo, sino, más bien, con "el mundo que han formado o constituido los hombres", que en general se puede calificar de antropológico-cristológico y soteriológico. En el prólogo joánico como en el EvJn aparece el mundo en primer lugar como sometido al pecado, al que se le ofrece la salvación $(1,5 \mathrm{a} .9 .10 \mathrm{a})$, pero luego como una magnitud cerrada a la revelación histórica de Jesús (1,5b.10c). En v. 10a es presentado el mundo más bien como el espacio habitable de los hombres; en v. 10c significa el mundo de los hombres cerrado a la luz; en v. 10b debería tratarse de una añadidura del evangelista. Esta conexión de la encarnación (v. 9c: "viniendo al mundo"); 10a: “... estaba en el mundo" con la afirmación de la creación (v. 10b: “... el mundo se hizo por medio de él”) quiere expresar que la venida del revelador por excelencia de la historia humana al mundo no está en oposición a la esencia del mundo sino que el origen del mundo depende del Verbo. En el v. 11 se dice que el Verbo vino a su propia casa. Por consiguiente es una evidente contradicción y contrasentido que el mundo no haya reconocido (= oủk éy $\nu \omega$ [uk egnō] la Sabiduría) a su creador. Jesucristo, el revelador del Padre en la historia, tenía derecho a que el mundo creyera por su dependencia de él como su creador $(1,3)$, pero el mundo le negó la fe (v. 10c). El mundo no lo conoció (= oủk '̌́ $\gamma \nu \omega$ [uk egnō]) no significa un mero conocer racional, "sino una aceptación dócil de la enseñanza divina ... y un seguimiento práctico de las instrucciones que le son dadas por medio de la Sabiduría, la Torá o el Verbo" ${ }^{45}$.

${ }^{45}$ R. Schnackenburg, I, 233. 
"Vino a su casa, pero los suyos no le recibieron $(1,11)$. El evangelista se refiere a la venida histórica del Verbo encarnado, que es idéntica con el pensamiento

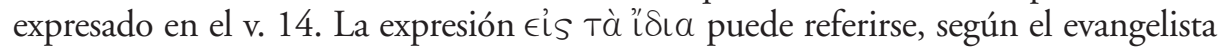
en el presente contexto, al pueblo judío de entonces que rechazó a Jesús, el revelador de Dios, como también a todo el mundo, es decir, al mundo de los hombres. En este punto varían las opiniones de los exegetas. La opinión de que $\epsilon i \mathrm{~s}$ Tà ỉ $\delta$ la (= su propia casa) o bien ó ísıo (= los suyos) puede significar el pueblo judío elegido corresponde al parecer del evangelista de que la llamada del Bautista se dirigía al pueblo de Dios: “... para que sea manifestado a Israel, para esto vine yo bautizando con agua" $(1,31 ; c f$. en cambio, la finalidad universal: “... para que todos $(=\pi \alpha ́ \nu T \in S$ [pantes]) creyeran por medio de él” (1,7c). La revelación de Jesús en su vida terrena se dirige exclusivamente al pueblo judío, que, sin embargo, le rechazó: "Habiendo hecho tantos signos delante de ellos no creyeron en él" $(12,37)$. Sin lugar a dudas, se mantiene en el EvJn, aunque muy relativizada, la historia salvífica del pueblo de Dios, muy subrayada, en cambio, en el AT y el judaísmo. La orientación históricosalvífica del EvJn, aunque muy reducida, tenía por objeto que los miembros del pueblo judío aceptasen las profecías de la Sagrada Escritura $(5,39)$, de Moisés $(5,46)$ y de los profetas $(1,23 ; c f$. también 12,40$)$, y creyeran en Jesús, la revelación de Dios Padre. El título "Israel” (1,31.49; 3,10; 12,13), o bien, "israelita" $(1,47)$ son ciertamente títulos honoríficos, pero solo en cuanto uno está dispuesto a creer en Jesús, tienen importancia. La oferta salvífica de la revelación histórica de Jesús al pueblo judío tuvo primacía sobre los samaritanos $(4,4-42)$ y los gentiles $(7,35 ; 10,16,11,52 ; 12,20-25)$, pero esos antiguos privilegios religiosos no tienen ya ninguna importancia respecto a la fe en Jesús $(2,19-21 ; 4,20-21)$. Esta interpretación y aplicación de las expre-

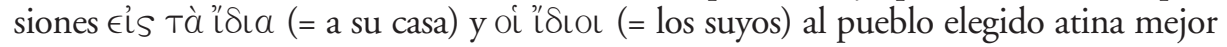
con la intención del evangelista en el prólogo de san Juan, si bien la polémica antijudía no se destaca aquí mucho ${ }^{46}$.

\subsubsection{La acogida del Verbo por los suyos (v. 12-13)}

Es extraño que después de la categórica afirmación de que "los suyos no lo recibieron" (v. 11b) se diga que "a cuantos lo recibieron, les dio el poder de ser hijos de Dios, a los que creen en su nombre" (v. 12). Tales aparentes contradicciones se encuentran con frecuencia en el EvJn: por una parte, se considera la impenitencia

${ }^{46}$ R. Schnackenburg, I, 236, no quisiera comprometerse con esa interpretación y considerar

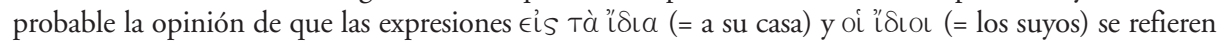
en dimensión universal al mundo de los hombres. Muy probable es que esas expresiones en el himno prejoánico aludían no al pueblo de Dios, sino a todo el mundo de los hombres, cuyo creador era el Verbo. Esa interpretación coincide con el motivo de la literatura de la Sabiduría. (Eclo 24,6-8). 
de los incrédulos judíos como definitiva e irreversible; por otra, Jesús habla de nuevo a los obstinados e incrédulos judíos para que se conviertan y crean en él ( $c f .8,23.24 \mathrm{a}$ con 8,24b; 8,25.26a con v. 8,26b.28; 12,37-41 con v. 42.44-50, etc.). Al evangelista le gustan las antítesis que expresan algo verdadero y fundamental como que Jesús no encontró en el judaísmo la fe esperada, pero no omite que hubo personas incluso procedentes de los círculos dirigentes del pueblo escogido por Dios que creyeron en él ( $c f .12,42-43 ; 19,38-39)$.

El v. 12 muestra en su lenguaje colorido joánico: las expresiones "recibir a

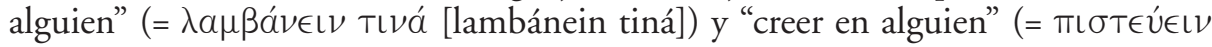
Eís Tıvá [pistéuein eis tiná]) son consideradas características joánicas ${ }^{47}$. La expresión "lo recibieron" equivale a "creer en su nombre". La acogida del Verbo, el enviado de Dios, encuentra precisamente en la Iglesia joánica la respuesta esperada de la fe verdadera. La terminología cristiano-joánica indica que el v. 12, como ya antes los vs. 9-11, se refieren a la acogida del Verbo encarnado. La fe cristiana es la condición para ser hijos de Dios adoptivos, el regalo por excelencia del Verbo encarnado ( $c f$. la estructura del v. 12: [a] "recibir"; [b] "poder de ser hijos de Dios"; ['a] "fe"). Una señal de que es cristiana la expresión "(los) hijos de Dios" (cf. 11,52) (= [Tà] Tékva [Toû] $\theta \in$ ô̂ [ta tékna tu zeú]) es que no se encuentra ni en la Biblia griega (= LXX), ni en la literatura judía. Ciertamente se encuentra el significado de "hijos de Dios" en lugares en que no aparece toda la expresión, sino solo "hijos" (= Té Kva) (Dt 32,5; Is 30,1; 57,4; 63,8; Jer 3,19; Sab 16,21), pero incluso en esos lugares se les reprocha a los israelitas sus malas obras, a excepción de Sab 16,21, o en su contexto (Jer 3,19-20). La expresión vioi tov̂ $\theta \in$ ov̂ (= [uiói tu zeú] "hijos de Dios", pero nótese que es griega) aparece bastante frecuentemente en la Biblia griega (Dt 14,1; Sab 2,18; 5,5; 18,13) sin contar las formas "mis hijos", "tus hijos, sus hijos en relación con Dios, pero, en cambio, se observa una fuerte reserva en el empleo de la palabra griega Tékva ("hijos" [tékna]) para expresar la relación filial de Israel con respecto a Dios en el AT y la literatura judía: los judíos no son llamados en la Biblia griega Tékva тôิ $\theta \in \mathrm{O}$ (tékna tu zeú ["hijos de Dios" con esta expresión griega]). En el NT es distinto: en San Pablo y en los escritos joánicos se encuentra la expresión Tékva $\theta \in$ ô̂ (Jn 1,12; 1 Jn 3,1-2; Rom 8,16; Flp 2,15) o тékva тoû $\theta \in$ ov̂ (Jn 11,52; 1 Jn 3,10; 5,2; Rom 8,21; 9,8) para referirse a la relación de filiación divina adoptiva de los cristianos con Dios Padre. En San Pablo, además, los cristianos son llamados también víó (= uiói) $\theta \in o \hat{~}$ (Rom 8,14.19; 9,26; Gál 3,26), locución que expresa la misma relación de filiación adoptiva que Téкva; en el EvJn y las cartas joánicas se reserva solamente a Jesús el

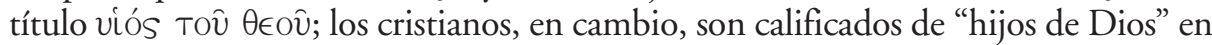
sentido adoptivo con la expresión griega Tékva Tov̂ $\theta \in \mathrm{O}$, pero no con la de vioí

${ }^{47}$ E. Ruckstuhl, Die literarische Einheit des Johannesevangeliums, Friburgo Suiza 1951, 204 (núm. 23.24). 
(= uiói) $\theta \in o ̂$ como en San Pablo, como se acaba de indicar ${ }^{48}$. En el prólogo se otorga

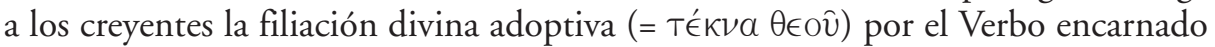
(v. 12-13); en Jn 3,3.5.7-8 les es conferido el engendramiento o la generación divina o filiación divina por el Espíritu y el Bautismo. De este modo se evita, por una parte, la deificación mística o individualista de las religiones no cristianas, y, por otra, se realza sublime y divinamente la dignidad de los discípulos de Jesús en relación con Dios por medio del Espíritu (3,3.5.7-8) o el Verbo encarnado (1.12-13) y el Bautismo (3,3-9). El sintagma nominal (Tà) Tékva Tô̂ $\theta \in o \hat{~ e x p r e s a ~ a s i m i s m o ~ l a ~ i d e a ~ d e l ~ n u e v o ~}$ o verdadero pueblo de Dios, cuyos miembros convertidos en hijos de Dios y herederos del reino de Diospor el Espíritu y el Bautismo (3.3.5) forman la Iglesia, en concreto, la iglesia o comunidad joánica.

El v. 13, unido algo sueltamente al v. 12, intenta aclarar posteriormente el acontecimiento de la filiación divina de los hijos de Dios, "que no han nacido

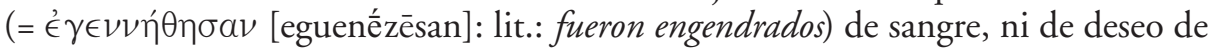
carne, ni de deseo de varón, sino que han nacido de Dios". Intentar sacar un argumento para el nacimiento virginal de Jesús del v. 13 es exegéticamente abusar del texto de $1,13^{49}$, pues no solo se excluiría al padre terreno (v. 13c: “... ni de deseo de varón”), sino también a la madre (v. 13a: "... que no han nacido de sangre"). Por eso algunos exegetas no quisieran referir la afirmación del v. 13 ni a los creyentes en general, ni al Verbo encarnado, sino al Verbo "no encarnado" (ä баркоs) $)^{50}$. En verdad en el v. 13 no se trata del nacimiento virginal de Jesús, ni de la generación del Verbo por Dios Padre, sino de la generación de los creyentes por Dios (= Téкva Toû $\theta \in \mathrm{O}$ ). Ese tema se trata más ampliamente en Jn 3,3-9. En 1,12-13 se atribuye al Verbo el que los creyentes reciban por medio del Bautismo la filiación adoptiva o el don de poder ser "hijos de Dios" (= Tékva Tô̂ $\theta \in \mathrm{OU})$, aunque las tres personas de la Ssma. Trinidad en realidad obran juntas, como cuando actúan ad extra, o sea, fuera de las relaciones subsistentes que constituyen las personas divinas.

\subsubsection{La encarnación del Verbo y la confesión de fe de los creyentes (v. 14)}

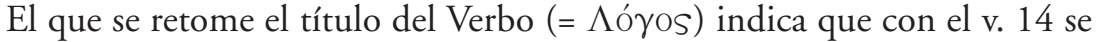
produce un corte o una cesura en el prólogo de San Juan, y que comienza una nueva

${ }^{48}$ A.P.J. Arowele, Diaspora-Concept in the New Testament (Inaugural Dissertation), Würzburgo 1976, 461-462; M.E. Boring, "The Influence of Christian Prophecy on the Johannine Portrayal of the Paraclete and Jesus": NTS 25 (1979), 120.

${ }^{49}$ Desde el punto de vista crítico-textual esta lectura está débilmente atestiguada, pues no se encuentra en ningún manuscrito griego importante.

${ }^{50}$ Cf. P. Hofrichter, Im Anfang war der 'Johannesprolog', Ratisbona 1986, 45-54. 
sección. Se puede decir que el prólogo consta de dos partes (1-13; 14-18), y no de tres $(1-5 ; 6-13 ; 14-18)$, como insinuaría mi división. Me he inclinado anteriormente por la división tripartita, porque la parte segunda (6-13), según mi división, no se refiere pura y nítidamente a la primera del Verbo äбapкоs, donde solo se habla del Verbo no encarnado (1-5), sino que está orientada a la tercera (14-18), que se refiere

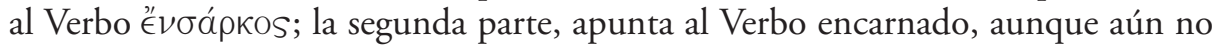
se haya mencionado explícitamente la encarnación del Verbo $(c f .1,14 \mathrm{a})$.

El v. 14 se compone de tres afirmaciones, que están unidas por la conjunción "y" (кai). La primera conjunción " $y$ ", al principio del v. 14a, equivale a "y verdaderamente", "efectivamente". Aquí se destaca la realidad de la encarnación del Verbo encarnado del que se viene hablando desde el v. 6-8. Con el v. 14 comienza, además, una forma comunitaria de confesión en el "estilo-nosotros".

La primera afirmación reza: "Verdaderamente el Verbo se hizo carne" (Kaì

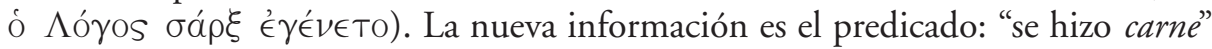

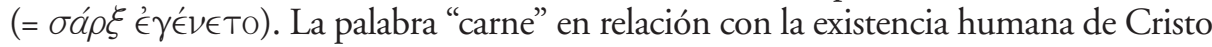
aparece en la confesión de Rom 8,3: Dios "envió a su propio Hijo en semejanza de carne de pecado y en orden al pecado, condenó el pecado en la carne". La palabra $\sigma a ́ p \xi$ (= sarx) significa aquí como en el AT lo terreno, lo caduco que caracteriza la existencia humana que se diferencia de la esencia divina y que es todo lo contrario de

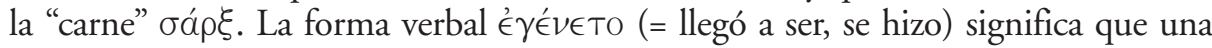
cosa o persona cambia su cualidad o atributo, entra en un nuevo estado o condición, que se convierte en algo que no era antes ${ }^{51}$. En los libros de la Antigüedad se lee que los dioses se aparecían como hombres, pero no se dice que aparecieran en carne y menos que se hayan hecho o se hicieran carne. En las primitivas confesiones de fe se afirma, en cambio, que Dios envió a su propio Hijo en semejanza de carne de pecado" (Rom 8,3) o que él (Jesucristo) "fue manifestado en la carne" (1 Tim 3,16b). Pero la comparación de estos pasajes paulinos con el v. 1,14a: "Y el Verbo se hizo carne" hace resaltar el realismo de esta afirmación del prólogo joánico: El Verbo que estaba junto a Dios y era de la esencia del único Dios y estaba lleno de la vida de Dios, entró en la esfera de lo terreno-humano, de la materia de lo efímero, perecedero, haciéndose carne ${ }^{52}$. No se puede hablar, por tanto, de la encarnación del Verbo como de una epifanía o manifestación del Verbo en sentido mitológico, sino de una encarnación verdaderamente real. La afirmación del acontecimiento: "el Verbo se hizo carne u hombre" se puede transformar lógicamente como una afirmación que expresa la identidad esencial del Verbo: "El Verbo es ahora carne u hombre". Respecto a la afirmación del acontecimiento de la encarnación del Verbo, el evangelista está solo interesado

\footnotetext{
${ }^{51}$ Cf. W. Bauer, Wb 316.

${ }^{52}$ Cf. R. Schnackenburg I, 241.
} 
en el "que", no en el "cómo" se realizó la encarnación. El relato lucano de la anunciación (Lc 1,34) así como nuestro credo niceno-constantinopolitano están especialmente interesados en el cómo del nacimiento de Jesucristo: "Et homo factus est ex Maria Virgine ...". Por consiguiente, la afirmación "el Verbo se hizo hombre" (= kai

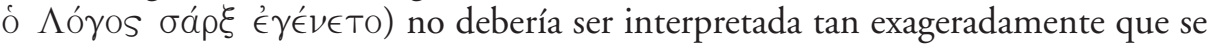
busque en ella un fuerte acento antignóstico, como pretende R. Bultmann, o una expresión mitológica, como E. Käsemann, según el cual la encarnación no representa más que lo mínimo indispensable para realizar su misión, mostrándose semejante a los hombres entre los que vivió por poco tiempo ${ }^{53}$.

La considerada por R. Bultmann y por otros - p. ej. G. Richter- como orientación antignóstica o antidoceta no se tiene hoy por muchos exegetas como muy probable: en primer lugar, la palabra "carne" (= $\sigma a ́ p \xi)$ aparece en confesiones de fe primitivas (Rom 8,3) sin connotaciones antignósticas; en segundo lugar, se podría decir que a la obra del evangelista le falta una intención polémica contra la gnosis y el docetismo; en tercer lugar, es sumamente dudoso que existiera la gnosis reconstruida por R. Bultmann o la "nueva gnosis" de G. Richter en el tiempo del EvJn. El gnosticismo con sus sistemas gnósticos, que nos han trasmitido los padres de la Iglesia, es bastante posterior al EvJn, tal vez, por lo menos, 40 años más tarde. Creíamos que podíamos darnos satisfechos con lo que sabemos sobre el docetismo, y tener una cierta certeza de que ha influído sobre los escritos más recientes del NT, pero nuevos estudios parecen disuadirnos de semejante optimismo ${ }^{54}$.

Si se examinan a fondo las afirmaciones cristológicas del evangelista sobre la encarnación en el prólogo y en todo el EvJn es evidente que el evangelista siente interés por recalcar que Jesús de Nazaret es el Verbo encarnado, y que está obligado a hablar de la encarnación porque sabe que esta fundamenta la experiencia salvífica de los creyentes, que depende del Verbo encarnado, o sea, de la"carne" que él asumiera. Aquí conviene recordar lo que dijera el arriba mencionado M. Henry sobre la "carne" en sentido bíblico. En el himno prejoánico, por el contrario, no se ponía el acento sobre la revelación del Verbo encarnado sino sobre la entrega del Verbo encarnado a la muerte por sus fieles. En el himno prejoánico se ponía probablemente un acento especial sobre el Verbo encarnado que se había entregado a la muerte, mientras que el evangelista contempla al Verbo hecho hombre como la revelación

${ }^{53}$ Cf. E. Käsemann, Jesu letzter Wille, 35: contra la opinión de E. Käsemann habla la construcción lingüística de 1,14a; W.Bauer Wb 316; K. Berger, "Zu 'Das Wort ward Fleisch', Joh 1,14a”: NT 16 (1974) 160-165: el intento de traducir $\gamma(v \in \sigma \theta a$ a en el sentido de aparecer no ha tenido suerte. La cristología de los logia del Hijo del hombre no favorece la supuesta cristología doceta del EvJn: F.J. Moloney SDB, The Johannine Son of Man, Roma 1976; para otros rasgos antidocetistas en EvJn cf. G. Richter, Studien zum Johannesevangelium, Ratisbona 1977.

${ }^{54}$ Cf. J.-D. Dubois, "Le docétisme des christologies gnostiques revisité": NTS 63 (2017) 279-304, espec. 303-304. 
de Dios en la realidad histórica. En todo el EvJn no se encuentra tan fuertemente subrayado el carácter sacrificial de la muerte de Jesús como en el himno prejoánico ( $c f$. los vs. 10-11.14.16, que muy probablemente, por lo menos, en buena parte pertenecían al himno primitivo). En 1,14 se menciona explícitamente la $\sigma a ́ p \xi$ (= [sarx] carne), que hace posible la entrega sacrificial, a la cual se alude al principio $(1,29 \mathrm{~b})$ $y$ al final $(19,14.34 .36)$ del EvJn, tema fundamental que como un gran arco abarca el EvJn del principio al fin ${ }^{55}$. Sin entrega de la "carne" no sería posible la muerte sacrificial y la participación de los creyentes en ella ( $c f$. Jn 6,51-56).

La segunda afirmación "y habitó entre nosotros" $(1,14 \mathrm{~b})$ prolonga el acontecimiento de la encarnación por un lapso de tiempo; el tiempo de habitar en tienda

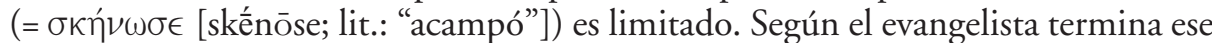
tiempo con el fin de las apariciones del Resucitado (20,19-29). Ese tiempo era el tiempo de los testigos oculares, al que ahora mira el evangelista retrospectivamente, y pertenece al pasado ( $c f$. el aoristo [= indefinido]: $\sigma \kappa \eta ́ v \omega \sigma \epsilon)$. El verbo $\sigma \kappa \eta \nu o v ̂ \nu$ (= acampar) ha sido escogido deliberadamente para aludir a la peregrinación del pueblo de Dios con el arca de la alianza por el desierto, que como el arca acampaba en tiendas - San Pablo habla de la "piedra que acompañaba" a los israelitas por el desierto, que era Cristo: $c f .1$ Cor 10,4 con Jn 6,9-11-. Las promesas que se contienen en estas representaciones no solo del arca de la alianza acampando en el desierto sino también en otros modos de presencia de Yahvé en el AT como en el templo, la Sabiduría (Eclo 24,8) o la Torá, se han cumplido ahora en Cristo ${ }^{56}$.

La confesión de la Iglesia: "... habitó entre nosotros y hemos visto su gloria" $(14 \mathrm{bc})$, se considera unida a la de los testigos oculares ( $c f .20,29$ : palabras del Resucitado a Tomás respecto a los futuros cristianos que no lo han visto, pero que creen o creerán igualmente). Esta confesión de la Iglesia, muchos de cuyos miembros no habían visto al Resucitado, pertenecía al himno prejoánico ${ }^{57}$.

En la tercera afirmación principal $(1,14 \mathrm{c})$ proclama la Iglesia su experiencia cristológica de Jesús exaltado y glorificado ( $c f$. Jn 8,28bc y 19,37): “... hemos contemplado (= aoristo, equivalente a indefinido español) su gloria" (= є̇ $\theta \in a \sigma a ́ \mu \in \theta \alpha$ [: ezea-

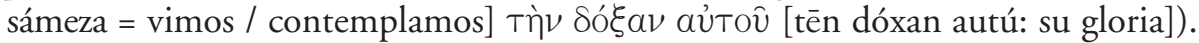

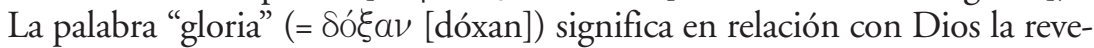
lación de su esencia, como en Ex 34,6: "Señor, Señor, Dios compasivo y misericordioso ... rico en clemencia y lealtad”. Las teofanías del AT tienen por objeto revelar su gracia y lealtad. Estas dos palabras corresponden a la gracia y verdad (= Xápıs

${ }^{55}$ En el EvJn podemos descubrir otros grandes arcos que abarcan el EvJn de un extremo al otro, como el arco cristológico de los títulos de Jesús en el prólogo y capítulo primero (1,1-18.1951) y en el último (20,31), el arco de las afirmaciones de preexistencia (1-2.15.30; 6,62; 8,58; 17,5.24) y el mariológico (2,1-5 y 19,25-27).

${ }^{56}$ Cf. M. Theobald, Im Anfang war das Wort, 56-60.

${ }^{57}$ Cf. M. Theobald, ibid., 56-57. 


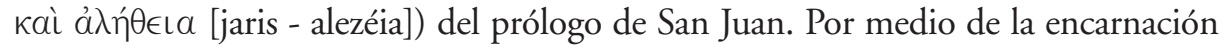
del Verbo, el Unigénito del Padre, se han manifestado y hecho realidades experienciales sobrenaturales la gracia y la verdad que tienen su origen en Dios Padre, cuyo mediador es Jesucristo (v. 14e.17b). Pero "gloria" que se ha revelado como gracia y verdad es en sentido estrictamente trinitario el Espítu Santo, como sabe todo exegeta o teólogo. La Iglesia supera, pues, absolutamente a Moisés, pues Moisés propiamente no ha visto a Dios: "Mi rostro no lo puedes ver, porque no puede verlo nadie y quedar con vida" (Ex 33,20.23); "A Dios nadie lo ha visto jamás" (Jn 1,18). Jesús revela en su ministerio público su gloria divina por medio de sus signos milagrosos junto con sus palabras reveladoras. Estas interpretan el significado cristológico de aquellos. Jesús le promete a Natanael y los discípulos: "Has de ver cosas mayores". Y le añadió: En verdad, en verdad os digo: veréis el cielo abierto y a los ángeles de Dios subir y bajar sobre el Hijo del hombre" (Jn 1,50-51). Esta promesa alude a las futuras autorrevelaciones de Jesús por medio de sus milagros-signos y discursos de revelación, que se narran en el corpus del EvJn (Jn 2,1-17,26). Con el milagro de Jesús en Caná de Galilea comienza a realizarse la promesa de Jesús, y los discípulos responden a su revelación: "Así manifestó Jesús su gloria y sus discípulos creyeron en él" $(2,11 \mathrm{~cd})$.

La revelación de la gloria de Dios Padre tiene lugar solo en la persona de Jesús, que no es humana, sino divina, por medio de sus milagros-signos y sus palabras o discursos. Esta revelación de la gloria de Dios Padre por Jesús se denomina joánicamente "verdad cristológica revelada" (= $\alpha \lambda \hat{\eta} \theta \in \iota \alpha)$. No debe separarse de su persona divina, de la realidad concreta, terrena de Jesús de Nazaret y de sus hechos milagrosos o milagros-signos, que se llaman en el EvJn séméia (plural neutro griego de sēméion [signo]) joánicos. R. Bultmann interpreta solo existencialísticamente la revelación de Jesús de Nazaret, es decir, como una "realidad reveladora divina" después de haberla desmitologizado la persona de Jesús así como su actividad milagrosa. Lo que queda de la desmitologización de la revelación divina queda sin concretizar, ni es tangible. La filosofía existencialista reemplaza a la fe verdadera o sobrenatural.

Ciertamente no es la verdad revelada joánica ningún concepto puramente intelectual, exclusivamente racional, sino una realidad divina revelada y revelante, que está esencialmente unida a su persona divina. Con palabras más precisas: la revelación o verdad joánica se identifica con la persona del Verbo encarnado y con su obra terrena salvadora que culmina en su muerte en la cruz, que el evangelista llama "su exaltación" (3,14; 8,28; 12,32.34) y "glorificación" (Jn 7,39; 11,4; 12,16.23.28; $13,31 ; 17,1.5)$. Jesús de Nazaret es para el evangelista, según Bultmann, solo un hombre, aunque el evangelista no haya procedido siempre - como insiste el exegeta de Marburgo - con suficiente consecuencia y radicalidad. Bultmann sí que pretende proceder con radical consecuencia. Lo único divino que queda de Jesús y en lo que nadie puede comparársele, dice Bultmann, es que es el único que habla la Palabra de Dios, como ningún hombre lo haya hecho, pero entiéndase correctamente, es decir, existencialmente — como Bultmann pretende-. Su discípulo E. Käsemann contradijo al maestro. Si Bultmann propugnó una teología de la cruz (theologia crucis), defiende E. Käsemann la teología de la gloria (theologia gloriae). Según Käsemann, la afirmación "la Palabra o el Logos se hizo carne" está a la sombra, 
por así decir, de la otra afirmación "Hemos contemplado su gloria"s8. Así puede afirmar, siguiendo la teología liberal, que el Jesús del EvJn es "el Hijo de Dios caminando por el mundo de los hombres" y su vida terrena "es el espacio en que irrumpe la gloria del cielo" 59 . "Sin un mínimo de esplendor milagroso que le caracterice como creador no es posible la revelación de Dios en la tierra; los milagros no son, por tanto, superfluos y concesiones a la debilidad humana, como pretendía Bultmann ${ }^{60}$.

Desde el punto de vista puramente exegético no podemos decidirnos unilateralmente, ni por la interpretación de Bultmann, ni por la de Käsemann. Con Bultmann hay que aceptar seriamente la afirmación "el Logos se hizo carne", pero también hay que tomar seriamente la experiencia de la autorrevelación divina del Logos hecho hombre ${ }^{61}$. El defecto de ambas respuestas es que son equívocas: En Bultmann no se da una verdadera encarnación, porque el Logos preexistente es un mito y para E. Käsemann también. Además, los supuestos histórico-religiosos en que se basaban las opiniones de ambos exegetas y teólogos protestantes acerca de la gnosis, gnosticismo y el docetismo, a que ya hemos aludido, se consideran hoy día anticuados o están superados; son controvertidos o rechazados: el gnosticismo descrito por los padres de la Iglesia con sus desarrollados sistemas aparece casi medio siglo más tarde que el EvJn y los escritos joánicos; tampoco es creíble que cuando se escribió el EvJn existiera la gnosis descrita por Bultmann, y ni siquiera la "nueva gnosis" de sus "nietos espirituales" a raíz de la publicación de los textos gnóstico-coptos de Nag-Hammadi (L. Schottroff; G. Richter; Langbrandtner; J. Becker). También en torno al docetismo hay recientes estudios, como se dijo anteriormente. Por otra parte, el AT, especialmente, con sus tradiciones sapienciales, y el Judaísmo con las judías del segundo templo así como los estudios targúmicos, que hoy día han alcanzado más importancia de la que tenían en tiempo de R. Bultmann y E. Käsemann, han de ser tenidos en cuenta, cosa que no pudieron hacer estos grandes exegetas.

\subsubsection{El segundo testimonio de Juan el Bautista a favor del Verbo preexistente, encarnado (v. 15)}

El segundo testimonio del Bautista intercalado entre los vs. 14 y 16 causa una impresión brusca e inesperada: $c f$. el estilo "nosotros" (v. 14) — "yo" (v. 15) nosotros (v. 16). La ilación de las ideas entre el v. 14 y y el v. 16 queda interrumpida por el v. 15. Este versículo es la prueba más clara de que el prólogo de San Juan no es

\footnotetext{
${ }^{58}$ Cf. E. Käsemann, Jesu letzter Wille, 28.

${ }^{59}$ Cf. ibid., 35.

${ }^{60}$ Cf. ibid., 51-52.61.

${ }^{61} C f$. M. Theobald, ibid., 54-55.
} 
de una pieza. Aunque el arte del evangelista es aquí algo desigual, sin embargo, cuadra bien con el contexto. Por una parte se subraya la preexistencia eterna del Verbo encarnado antes de la creación del mundo. Así se corrobora que la comunidad cristiana, a la que pertenecen los testigos oculares de la actividad reveladora de Jesús y de los receptores de sus apariciones pascuales $(20,19-29)$ así como las generaciones cristianas posteriores $(20,29 \mathrm{~b})$, han experimentado y contemplado verdaderamente su gloria. Por otra, se recalca que la revelación divina se ha realizado real y verdaderamente en Jesucristo. La inserción de un testigo histórico, como es el Bautista, sirve para confirmar que "el Verbo se hizo carne" u hombre: Jesús de Nazaret es el Verbo encarnado, el revelador de la historia.

A parte de ese significado positivo contiene el v. 15 connotaciones polémicas contra los discípulos, que hacían la competencia a la comunidad joánica. Es decir, tenían a su maestro, Juan el Bautista, por superior a Jesús, porque Jesús apareció en público después del Bautista. Por esta razón, se realza la primacía de Jesús, o sea, su preexistencia, según el contexto del prólogo. Juan Bautista se convierte en el portavoz de la Iglesia joánica, quien aconseja a sus discípulos que sigan a Jesús ( $c f$. $1,35-37 ; 3,26-30)$. Sin embargo, al Bautista no se le convierte en discípulo de Jesús o en miembro de la Iglesia porque continúa su actividad bautista con su grupo.

Desde el punto de vista de la tradición, hay que indicar con respecto al dicho del v. 15cd procedente de la tradición sinóptica ("el que viene detrás de mí, se ha puesto delante de mí, porque existía antes que yo") que el Bautista, o en realidad el evangelista, trae una cita propia como si ya la hubiera pronunciado antes, pero que, en realidad, aún no fue pronunciada en el EvJn, sino que tendrá lugar más tarde (1.30). El evangelista supone en sus lectores o lectoras u oyentes un cierto conocimiento de la tradición sinóptica.

\subsubsection{Continuación de la confesión de la comunidad respecto a su participación en la historia de la salvación (v. 16)}

Según el contexto actual parece como si fuera el Bautista, que representa a todos los creyentes, el que recitase el v. 16. Sin embargo, según el EvJn, no pertenece a la comunidad cristiana o la Iglesia; por tanto es inadmisible poner en sus labios la frase siguiente: "Pues de su plenitud todos hemos recibido ... ". Los que la recitan

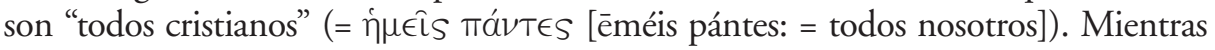
que en el v. 14a-e los que atestiguaban y profesaban su fe eran los testigos oculares, sin excluir a los futuros creyentes, en el v. 16 se expresa la experiencia común de todos los creyentes respecto al evento de la salvación ( $c f .17,20-21$ : estos dos versículos serían una añadidura inspirada de un glosista de la comunidad joánica, distinto del evangelista o su redactor, dentro aún de la época apostólica, que quería incluir a las generaciones cristianas futuras, que no habían conocido a Jesús, dentro de la oración de Jesús, el Hijo, enviado por el Padre [Jn 17,3-4.8-9.18.21e.23d.25e]). El evangelista mismo distingue también entre testigos oculares y cristianos posteriores, que han creído sin haber visto $(20,29)$. 
La palabra $\pi \lambda \hat{n} \rho \omega \mu \alpha$ (= plenitud [plếrōma]) hace suyo el pensamiento de $\pi \lambda \hat{p} \rho \eta \mathrm{s}$ (= lleno [plếrēs]) del v. 14. La palabra $\pi \lambda \hat{\eta} \rho \omega \mu \alpha$ se encuentra con frecuencia en los sistemas gnósticos; aquí en el prólogo no se refiere al ámbito del Logos, que incluiría todos los "eones" o mundos y emanaciones según el gnosticismo de los sistemas de mediados del siglo II d. C. En el v. 16 se refiere la abundancia salvífica de Jesús "a la riqueza de vida que el Verbo recibe y posee del Padre $(c f .5,26)$ y de la que hace partícipes a los suyos $(10,10) "{ }^{\prime \prime}$. La expresión Xápıs ả tos [gracia tras gracia]) no se refiere, como pensaba Orígenes, a las dos gracias, a la del NT que sustituye a la del AT. La mencionada expresión tiene, más bien, fuerza dinámica, o sea, significa el continuo e incesante crecer de la vida divina de los o en los creyentes: "gracia y siempre más gracia, y de nuevo más gracia", podríamos traducir. Esa experiencia de la revelación siempre en crecimiento alcanza su punto culminante en la perfecta fe pascual: "En aquel día conoceréis vosotros que yo estoy en mi Padre, y vosotros en mí y yo en vosotros" $(14,20)$. El Espíritu de la Verdad guiará

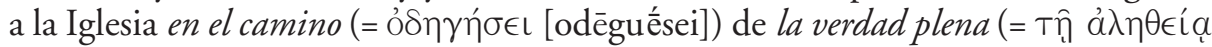
Táợ̂ [tè alēzéia]: Jn 16,13b) ${ }^{63}$. Pero esa revelación de la verdad plena aguarda la revelación plena y totalmente desvelada en la comunidad y comunión con Cristo, que no cesará jamás (Jn 17,24).

\subsubsection{Contraposición entre Moisés y Jesucristo respecto a su respectiva mediación religiosa ( $v .17)$}

Como en los vs. 6-8.15, vuelven a aparecer al final del prólogo (v. 17-18) los dos personajes más importantes, cuyo papel define brevemente el evangelista en el v. 17. Los vs. 17-18 pertenecen claramente al evangelista. Para comprender y resolver bien la cuestión, conviene entender la importancia que tienen para el evangelista en el EvJn los diversos personajes del AT (Moisés, Abrahán, Isaías) y las instituciones del AT y del Judaísmo (el templo, la Ley o Torá, la circuncisión, el pueblo de Dios). El evangelista no tiene interés alguno en desvalorizar la ley mosaica, la circuncisión, etc. Desde el punto de vista histórico-salvífico son irrelevantes, indiferentes. Estas instituciones judías no son malas en sí, pero carecen de toda importancia salvífica. Lo único importante es la fe en Jesucristo. Estas instituciones anticotestamentarias y judías (templo, Ley, etc), ritos, como los de los capítulos 7,37-39; 8,12, los ritos del agua y la luz en la fiesta de las tiendas o los sucesos del pasado del AT (maná

${ }^{62}$ Cf. R. Schnackenburg I, 251.

${ }^{63}$ El adjetivo griego máọ̣ (= pasē) significa toda la verdad en general y en su totalidad y en todas sus partes concretas, o sea, donde haya algo de verdad auténtica, allí alcanzará su colmo y perfección. 
en el desierto: $c f$. Jn 6,31-33) pueden servir de puntos de partida o contacto para los discursos de revelación de Jesús. Con respecto a las personajes del AT, como Moisés e Isaías, es inapreciable su significado profético, pues profetizaron sobre Jesús (5,46; 12,38-41). Como se relativiza la figura del Bautista y la de Moisés, así también es relativizada y subordinada la figura de Abrahán (8,33-41.51-57) a la persona del Verbo encarnado. "Antes de que Abrahán existiera, yo soy" $(8,58)$. Si Moisés es el mediador de la Ley, infinitamente mucho más importante es "Jesucristo, por medio del cual nos han llegado la gracia y la verdad" (v. 17).

\subsubsection{Jesucristo es el Dios unigénito y el exclusivo y único Revelador, que ha visto al Padre y nos lo ha dado a conocer (v. 18)}

Para los rabinos del tiempo del evangelista era un dogma incontrovertible que ningún hombre puede ver a Dios: Dios es para el hombre inaccesible y del que no puede disponer. Un eco de esta fe judía encontramos en algunos pasajes del EvJn: "Nadie ha subido al cielo sino el que bajó del cielo, el Hijo del hombre $(3,13)$; "Nunca habéis escuchado su voz, ni visto su rostro" $(5,37)$; "No es que alguien haya visto al Padre" $(6,46)$. En el tiempo del evangelista del EvJn había, sin embargo, tendencias e intentos místicos en ciertos círculos judíos que aspiraban a una unión inmediata con Dios mismo; se afirmaba incluso que Moisés había visto a Dios inmediatamente. El evangelista con la afirmación de que "nadie ha visto a Dios" (v. 18a) rechaza tales pretensiones místicas. Para el evangelista es indiscutible que solo Jesucristo ha visto al Padre porque tiene su principio en Dios $(6,46)$. Esto no se debe a éxtasis o ascensión mística, sino a que él viene del cielo $(c f .1,1-2 ; 3,13)$. Jesucristo, Dios unigénito ${ }^{64}$, permanece o permanecía en unión y comunidad personal con el Padre: “... que está (o estaba) en seno del Padre" $(1,18 \mathrm{~b})$. En la última cena el DA (= Discípulo Amado) "está reclinado ... en el seno de Jesús" $(13,23)$, expresión muy semejante a la del prólogo $(1,18 \mathrm{~b})$. Con ambas locuciones se expresa la unión personal del Verbo con Dios Padre, como la del DA con Jesús. Así como el Verbo es la Palabra (= Logos) del Padre, a su vez es el DA, el autor del EvJn, el intérprete de Jesús para la comunidad o Iglesia joánica por medio de su evangelio $(c f .21,24)$. Jesucristo es el exegeta o intérprete de Dios Padre por excelencia, porque estaba o está junto al Padre $(1,1$ bc y 1,18$)$ y nos ha dado a conocer (= É $\xi \eta \gamma \eta ́ \sigma a t o$ [exēguésato: la palabra exégesis tiene que ver con "explicar" y "dar a conocer"]) su revelación o sus palabras divinas.

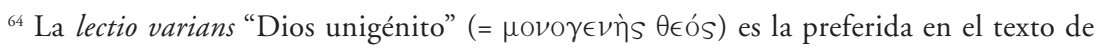
Nestle -Aland por tener a su favor los testigos más antiguos: $\mathrm{P}^{66} \aleph^{*} \mathrm{~B} \mathrm{C}^{*} \mathrm{~L}$. 


\section{CONCLUSIÓN}

Nos hemos reducido a estudiar sincrónicamente la cristología del prólogo de San Juan. Si hubiéramos intentado recomponer diacrónicamente el himno que subyace al prólogo de san Juan, el artículo se hubiera alargado mucho más, porque la reconstrucción del himno es insegura y más abundante en hipótesis y hubiera que haber refutado bastantes reconstrucciones del himno poco fiables. Quede eso para otra ocasión.

He intentado principalmente aprovechar los últimos trabajos sobre el EvJn de exegetas de habla alemana, pero también me ha llevado tiempo el estudio de algunos libros del filósofo francés Michel Henry, que aplica al EvJn una fenomenología "radical", es decir, rechaza la fenomenología anterior desde Edmundo Husserl a Merleau-Ponty, pasando por Martin Heidegger, porque se han quedado encerrados en el mundo y sus categorías intramundanas. Pues aquí se plantea la cuestión de qué hermenéutica necesitamos para interpretar más profundamente el EvJn. Para M. Henry es Cristo o la fe en Cristo adonde tienen que llegar los fenomenólogos: C'est moi la vérité, es el título de uno de los últimos libros de M. Henry. Esto es de alabar, aunque hemos indicado algunos serios errores teológicos en la interpretación de M. Henry. El prólogo de San Juan contiene una tan rica y alta cristología que se puede considerar una cima maravillosa del EvJn. El prólogo comienza proclamando que el Verbo preexistente, que estaba junto a Dios Padre, era (y es) Dios (v. 1-2), el creador de todo lo que existe (v. 3), la Vida misma que nos concede por medio de los sacramentos y sus palabras o discursos, y que deviene en luz de los hombres y brilla en la tiniebla (v. 4-5); la Luz verdadera iluminadora, que experimenta rechazo y acogida, y a los que le acogen les da el poder de ser hijos de Dios (v. 9-12). Es el Verbo encarnado, el Unigénito del Padre, lleno de gracia y verdad, de que participan todos los cristianos (v. 14.16). Es el verbo preexistente, cuyo pregonero por excelencia es Juan (v. 15). Si Moisés fue el gran el Legislador del AT, Jesucristo es infinitamente mucho más: el único e insuperable Mediador de la gracia y verdad entre Dios y los hombres (v. 17). El Verbo preexistente, que estaba junto al Padre (v. 1-2), es Jesucristo, el Dios Unigénito, que está en el seno del Padre, y como el Verbo encarnado se convierte en su exegeta o intérprete para los hombres (v. 18). 
